\title{
Technological Advancements for the Detection of Antibiotics in Food Products
}

\author{
Sonika Dawadi ${ }^{1,+}, \operatorname{Ranjita~Thapa~}^{1,+}{ }^{\oplus}$, Bindu Modi $^{1}{ }^{\oplus}$, Sobika Bhandari ${ }^{1}$, Arjun Prasad Timilsina ${ }^{1}{ }^{1}$, \\ Ram Prabodh Yadav ${ }^{1}$, Babita Aryal ${ }^{1} \mathbb{1}$, Sijan Gautam $^{1} \mathbb{D}$, Purnima Sharma ${ }^{1}$, Bijaya Bahadur Thapa ${ }^{1}$, \\ Niraj Aryal ${ }^{2}\left(\mathbb{D}\right.$, Sagar Aryal ${ }^{3}$, Bishnu P. Regmi ${ }^{4, *}$ and Niranjan Parajuli ${ }^{1, * \mathbb{C}}$
}

1 Biological Chemistry Lab, Central Department of Chemistry, Tribhuvan University, Kirtipur 44618, Nepal; sonikadawadi.sd@gmail.com (S.D.); acharya.ranjita08@gmail.com (R.T.); bindu.ms13@gmail.com (B.M.); sobikabhandari123@gmail.com (S.B.); arzun1777@gmail.com (A.P.T.); ramprabodh30@gmail.com (R.P.Y.); babitaaryal13@gmail.com (B.A.); sijangautam2550@gmail.com (S.G.); punamdevkota2052@gmail.com (P.S.); bijaya.chem@gmail.com (B.B.T.)

2 Pharmaceutical Institute, Department of Pharmaceutical Biology, University of Tübingen, 72076 Tübingen, Germany; aryal.niraj3@gmail.com

3 Kathmandu Research Institute for Biological Sciences, Lalitpur 44700, Nepal; sag.micro@gmail.com

4 Department of Chemistry, Florida Agricultural and Mechanical University, Tallahassee, FL 32307, USA

* Correspondence: bishnu.regmi@famu.edu (B.P.R.); niranjan.parajuli@cdc.tu.edu.np (N.P.)

+ Both authors contributed equally to this work.

check for updates

Citation: Dawadi, S.; Thapa, R.;

Modi, B.; Bhandari, S.; Timilsina, A.P.; Yadav, R.P.; Aryal, B.; Gautam, S.;

Sharma, P.; Thapa, B.B.; et al.

Technological Advancements for the Detection of Antibiotics in Food Products. Processes 2021, 9, 1500. https://doi.org/10.3390/pr9091500

Academic Editors: Enrico Marsili and Wei Ma

Received: 24 June 2021

Accepted: 24 August 2021

Published: 25 August 2021

Publisher's Note: MDPI stays neutral with regard to jurisdictional claims in published maps and institutional affiliations.

Copyright: (c) 2021 by the authors Licensee MDPI, Basel, Switzerland. This article is an open access article distributed under the terms and conditions of the Creative Commons Attribution (CC BY) license (https:// creativecommons.org/licenses/by/ $4.0 /)$

\begin{abstract}
Antibiotics, nowadays, are not only used for the treatment of human diseases but also used in animal and poultry farming to increase production. Overuse of antibiotics leads to their circulation in the food chain due to unmanaged discharge. These circulating antibiotics and their residues are a major cause of antimicrobial resistance (AMR), so comprehensive and multifaceted measures aligning with the One Health approach are crucial to curb the emergence and dissemination of antibiotic resistance through the food chain. Different chromatographic techniques and capillary electrophoresis (CE) are being widely used for the separation and detection of antibiotics and their residues from food samples. However, the matrix present in food samples interferes with the proper detection of the antibiotics, which are present in trace concentrations. This review is focused on the scientific literature published in the last decade devoted to the detection of antibiotics in food products. Various extraction methods are employed for the enrichment of antibiotics from a wide variety of food samples; however, solid-phase extraction (SPE) techniques are often used for the extraction of antibiotics from food products and biological samples. In addition, this review has scrutinized how changing instrumental composition, organization, and working parameters in the chromatography and CE can greatly impact the identification and quantification of antibiotic residues. This review also summarized recent advancements in other detection methods such as immunological assays, surface-enhanced Raman spectroscopy (SERS)-based assays, and biosensors which have emerged as rapid, sensitive, and selective tools for accurate detection and quantification of traces of antibiotics.
\end{abstract}

Keywords: antibiotics; solid-phase extraction; chromatography; capillary electrophoresis; surface-enhanced Raman scattering; biosensors

\section{Introduction}

Antibiotics are life-saving drugs, which have made a remarkable revolution in the medical sector in the twentieth century, but many antibiotics are now "endangered species" due to the global emergence of antibiotic resistance. These miracle drugs have substantially improved the life expectancy and health of humans and animals by combating a wide range of infectious diseases [1]. Most of the antibiotics are natural products that are secreted primarily by Streptomyces spp. [2]. Most commonly prescribed antibiotics in clinics are glycopeptides, polyethers, sulfonamides, tetracyclines, aminoglycosides, $\beta$-lactams, 
fluoroquinolones, and macrolides [3]. Among the several classes of antibiotics, most of them are classified based on their chemical structure, action mechanism, action spectrum, and route of administration [4]. Figure 1 depicts the various sources of how antibiotics reach up to our table $[5,6]$. Similarly, the structures of different classes of antibiotics are shown in Figure 2, and the examples of antibiotics belonging to the different classes are summarized in Table 1. Misuse and overuse of antibiotics in farming and subsequent contamination of the surrounding environment have been significantly linked with the emergence and spread of antimicrobial resistance (AMR). This increase also marks adverse effects on the food chain. A wide array of antibiotics, such as aminoglycosides, $\beta$-lactams, fluoroquinolones, and sulphonamides, etc., are reported as possible environmental pollutants by the World Health Organization; these are public health threats [7]. The emergence of antibiotic pollution has led to potential toxic effects on microorganisms, plants, animals, and ultimately humans [4]. When antibiotics are widely used, antibiotic-resistant bacteria evolved due to genetic or mutational alterations, which are also considered a new type of contaminant in the environment $[7,8]$. The uncontrolled use of antibiotics has made their presence almost everywhere in the environment, including water resources and soils. The wastewater and other biological wastes from farming soils, hospitals, and pharmaceutical industries may contain traces of antibiotics that could mix with water resources if discharged without proper treatment [9]. Hospital wastes are considered a breeding spot of antibiotic-resistant bacteria (ARB) [10]. ARB strains can survive and multiply even in harsh conditions compared to wild strains [11].

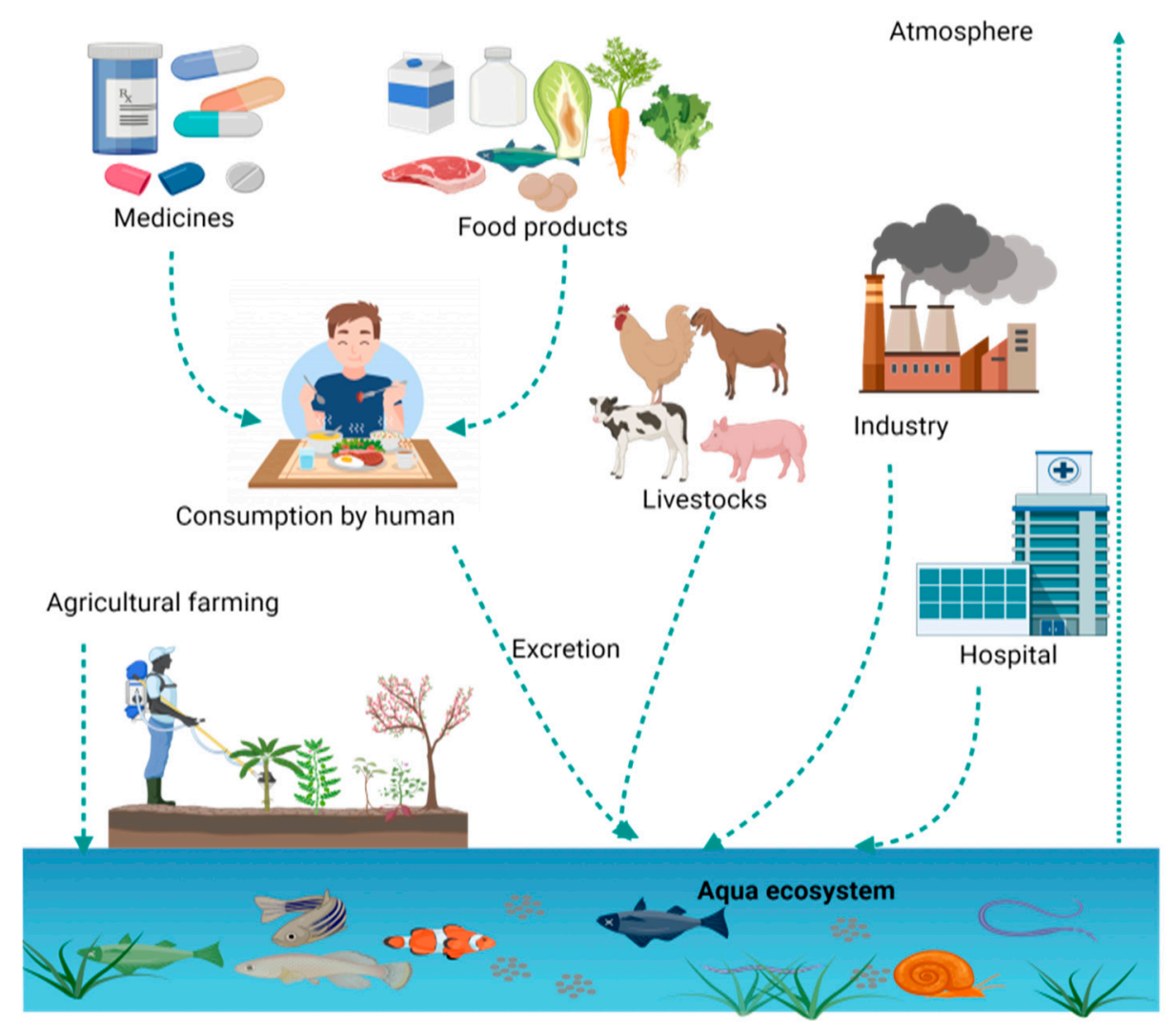

Figure 1. Pathways for antibiotic residues into the environment. 
<smiles>CC(=O)N1CCN(c2cc3c(cc2F)c(=O)c(C(=O)O)cn3C2CC2)CC1</smiles>

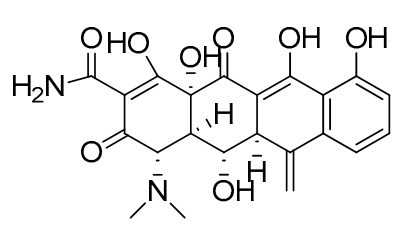

Methacycline<smiles>CN(C)[C@H]1C(O)=C(C(N)=O)C(=O)C2C(O)=C3C(=O)c4c(O)ccc(Cl)c4[C@@](C)(O)C3C[C@]21C</smiles>

Chlortetracycline<smiles>CCN[C@H]1C[C@H](N)[C@@H](OC2OC(CN)=CC[C@H]2N)[C@H](O)[C@@H]1OC1OC[C@@H](O)[C@H](NC)C1O</smiles>

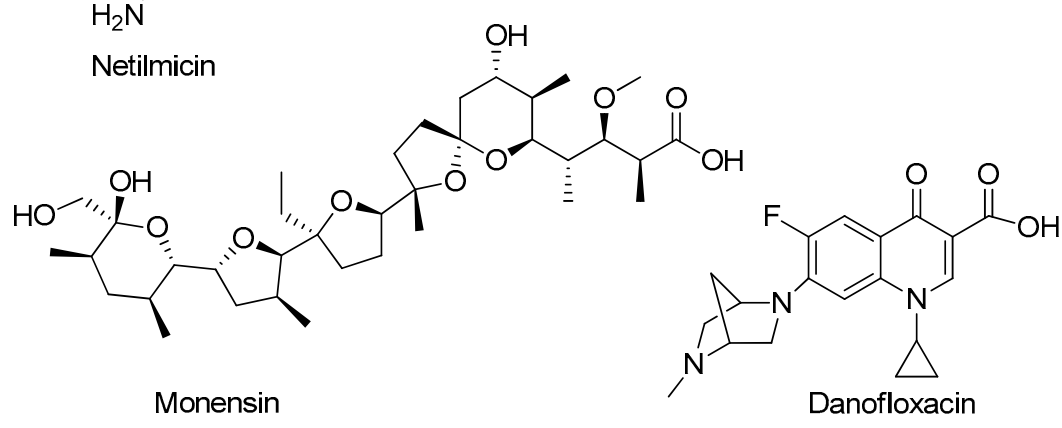<smiles>CC1SC2N(C(=O)C(N)c3ccccc3)C(=O)N2C1C(=O)O</smiles>

Ampicillin<smiles>CN1CCN(c2cc3c(cc2F)c(=O)c(C(=O)O)cn3-c2ccc(F)cc2)CC1</smiles>

Difloxacin hydrochloride

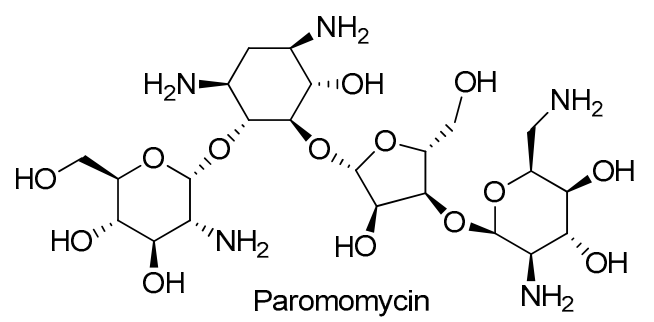<smiles>CC1c2cccc(O)c2C(=O)C2=C(O)[C@]3(O)C(=O)C(C(N)=O)=C(O)C(N(C)C)C3[C@@H](O)[C@H]21</smiles>

Doxycycline

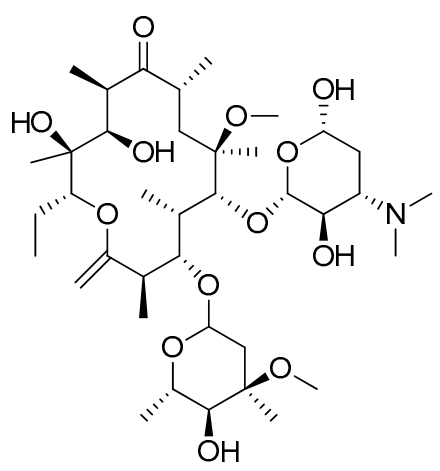

Clarithromycin<smiles>CO/N=C(\C(=O)N[C@H]1C(=O)N2C(C(=O)O)=C(COC(C)=O)CS[C@H]12)c1csc(N)n1</smiles>

Figure 2. Cont. 
<smiles>CC(=O)NS(=O)(=O)c1ccc(N)cc1</smiles>
Sulfacetamide

Sulfadiazine<smiles>Cc1cc(C)nc(NS(=O)(=O)c2ccc(N)cc2)n1</smiles>

Sulfamethazine

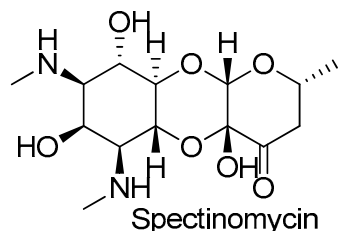

Spectinomycin<smiles>CN[C@H]1C(O)[C@H](O[C@@H]2C(N)CC(N)[C@H](OC3OC(CN)=CC[C@H]3N)C2O)OCC1(O)O</smiles>

Sisomicin<smiles>C=C(Cc1ccccc1)NC1C(=C)N2C1SC(C)(C)C2C(=O)O</smiles><smiles>CCn1cc(C(=O)O)c(=O)c2cc(F)c(N3CCNCC3)nc21</smiles><smiles>Nc1ccc(S(=O)(=O)Nc2ccccn2)cc1</smiles>

Penicillin G

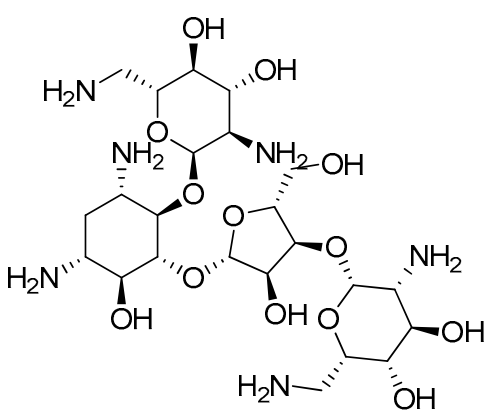<smiles>CCn1cc(C(=O)O)c(=O)c2cc(F)c(N3CCNCC3)cc21</smiles>

Enoxacin

Sulfapyridine<smiles>CNC1CCC(N)C(OC2C(N)CC(N)C(OC3OCC(C)(O)C(NC)C3O)C2O)O1</smiles>

Gentamicin C1<smiles>Nc1ccc(S(=O)(=O)NC2NN=CS2)cc1</smiles>

Sulfathiazole<smiles>Cc1onc(-c2ccccc2Cl)c1C(=O)NC1C(=O)N2C1SC(C)(C)C2C(=O)O</smiles>

Cloxacillin

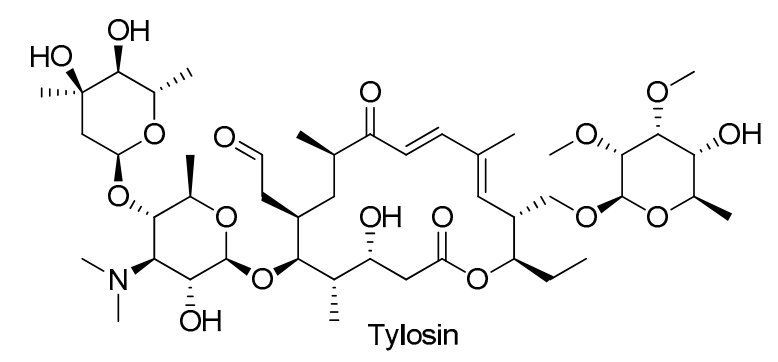<smiles>Cc1ccnc(NS(=O)(=O)c2ccc(N)cc2)n1</smiles>

Sulfamerazine<smiles>Cc1cc(NS(=O)(=O)c2ccc(N)cc2)no1</smiles>

Sulfamethoxazole<smiles>Nc1ccc(S(=O)(=O)Nc2ccc(Cl)nn2)cc1</smiles>

Sulfachlorpyridazine<smiles>O=C(N[C@@H](CO)[C@H](O)c1ccc([N+](=O)[O-])cc1)C(Cl)Cl</smiles>

Chloramphenicol<smiles>Cc1noc(NS(=O)(=O)c2ccc(N)cc2)c1C</smiles>

Sulfisoxazole

Figure 2. Structures of some antibiotics isolated from food products.

The presence of antibiotic residues in food products causes unfavorable effects on organ systems resulting in several health complications, such as immunopathological effects, skin allergy, mutagenicity, tuberculosis, liver problems, pneumonia, and even carcinogenicity in humans due to antibiotic-resistant bacteria $[12,13]$. To protect public health, maximum residue limits (MRLs) of antibiotics and other pharmacologically active substances in foodstuffs of animal origin were established by the European Commission $[14,15]$. In this connection, there have been significant efforts in the development of robust analytical methods with a combination of techniques such as High-Performance 
Liquid Chromatography (HPLC) coupled with Mass Spectrometry (MS), and Liquid Chromatography coupled with tandem mass spectrometry (LC-MS/MS) to monitor antibiotic residues in food products. Antibiotic residues may be present in food products, and it is often difficult to detect because residues are found to be associated with matrices, which interfere with their analysis [16]. In essence, a small portion of the initial antibiotics is likely to be bioactive, which challenges extraction of antibiotic residues as well as detecting and quantifying them [17]. Old-fashioned screening techniques, such as paper-based devices as $\mu \mathrm{PAD}$, are simple and affordable, but their sensitivity is not enough to capture antibiotic traces in food samples. Therefore, this need has led to the research and development of highly sensitive and selective analytical tools for the detection and quantification of antibiotic residues in complex matrices $[18,19]$.

The food consumed comprises nutrients including, however not limited to, lipids, proteins, and carbohydrates that form a complex food matrix. This matrix may interfere with the signals obtained for analysis; thus, the preconcentration step is carried out to minimize matrix interferences and to increase the sensitivity of detection [20]. The sample pretreatment is a challenging process since many antibiotics are thermally unstable and have no chromophore (e.g., aminoglycosides) [21]. Before instrumental analysis, different preconcentration/extraction processes, such as liquid-liquid extraction (LLE), SPE, liquidliquid microextraction (LLME), solid-phase microextraction (SPME), and magnetic solidphase extraction (MSPE), are used to isolate antibiotic residues from different samples [22]. SPE is also widely used for preconcentration and cleaning up steps since it is safer, easily operated, and efficient $[23,24]$.

Various analytical techniques such as chromatographic techniques (LC-MS/MS, UHPLCMS/MS, HPLC-ELSD), CE, immunological methods, SERS, and biosensors were employed to detect antibiotic residues. Chromatographic techniques are commonly used for the detection of antibiotic residues in food samples for a long period. A technique such as LC-MS/MS has become a mainstream technique for detecting antibiotics accurately and simultaneously in different environmental mediums [25]. Other determination techniques, such as CE [26], Raman spectroscopy [27], and enzyme-linked immunosorbent assays, are also employed in the detection of antibiotic residues [28]. Additionally, biosensors have emerged as an alternative method for screening antibiotic residues in different environmental, food, and biological samples. The use of biosensors in the detection of antibiotic residues is rapidly increasing because biosensors are rapid, sensitive, specific, and require little sample preparation. Additionally, they are affordable, simple to install, and can be operated by personnel with minimal training $[29,30]$.

Table 1. Major classes of antibiotics.

\begin{tabular}{|c|c|c|}
\hline Class & Examples & References \\
\hline Glycopeptides & $\begin{array}{c}\text { Vancomycin, Teicoplanin, Telavancin, Oritavancin, } \\
\text { Dalbavancin }\end{array}$ & {$[31]$} \\
\hline Sulfonamides & $\begin{array}{c}\text { Sulfacetamide, Sulfadiazine, Sulfathiazole, } \\
\text { Sulfapyridine, Sulfamerazine, Sulfamethazine, } \\
\text { Sulfamethoxazole, Sulfasoxazole, } \\
\text { Sulfachloropyridazine }\end{array}$ & [32] \\
\hline Tetracyclines & $\begin{array}{l}\text { Tetracycline, Oxytetracycline, Doxycycline, } \\
\text { Chlorotetracycline, Methacycline }\end{array}$ & [32] \\
\hline Aminoglycosides & $\begin{array}{c}\text { Amikacin, Paramomycin, Dihydrostreptomycin, } \\
\text { Hygromycin, Kanamycin, Netilmycin, Spectinomycin, } \\
\text { Sisomycin, Streptomycin, Tobramycin, Gentamicin, } \\
\text { Neomycin }\end{array}$ & [32] \\
\hline B-Lactams & Amoxicillin, Ampicillin, Cloxacillin, Penicillin G & [32] \\
\hline Macrolides & Erythromycin, Clarithromycin, Tylosin & [32] \\
\hline
\end{tabular}


Table 1. Cont.

\begin{tabular}{ccc}
\hline Class & Examples & References \\
\hline Fluoroquinolones & $\begin{array}{c}\text { Lomefloxacin, Ciprofloxacin, Enroflaxacin, } \\
\text { Danofloxacin, Difloxacin hydrochloride, Clinafloxacin }\end{array}$ & {$[31,32]$} \\
\hline Polyethers & Lasalocid, Salinomycin, Monensin, Narasin, Nigericin & {$[33]$} \\
\hline
\end{tabular}

\section{Extraction of Antibiotics from Food Samples}

The selection of suitable pretreatment methods is important due to the complexity of matrices and the low concentration of antibiotic residues in food samples. Solid-phase extraction (SPE) is the most extensively used pretreatment approach for the isolation and preconcentration of trace contaminants in complex samples (Figure 3). This is due to its convenience of use, minimal organic solvent consumption, and high enrichment factor [34]. The activation of the sorbent, percolation/sorption of the analyte in the sample matrix into the sorbent, removal of matrix interferences, and elution and concentration of the analyte with an appropriate technique are the key steps for a simple SPE procedure. However, the mechanism of extraction can vary depending on the nature of the sorbent used, and choosing an appropriate method of SPE for each application is vital [35]. The analysis of numerous classes of compounds using SPE format has used cartridges, different columns as classical SPE sorbents; however, the use of novel sorbent-based materials, such as metal-organic frameworks (MOFs), carbon nanotubes (CNTs), graphene oxide (GO), and molecularly imprinted polymers (MIPs) have brought about very good extraction recoveries with smaller amounts of sorbents, which are discussed below.

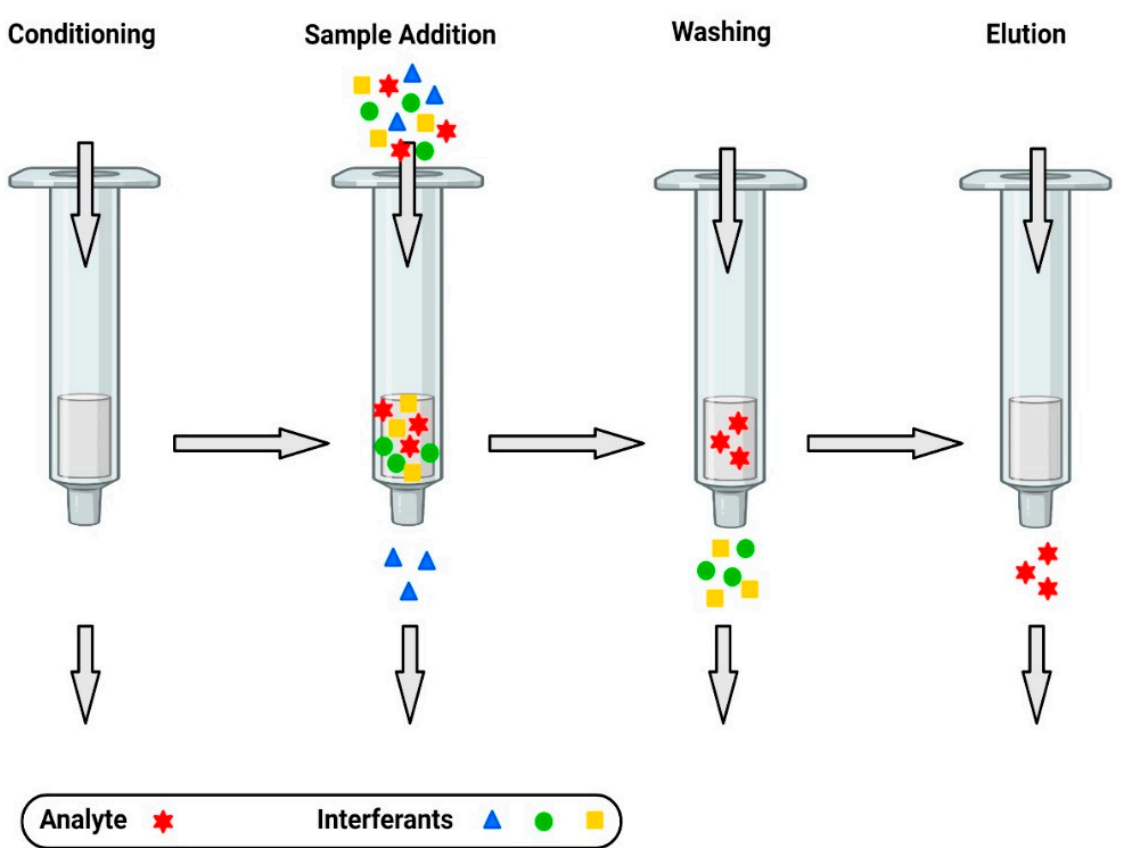

Figure 3. Typical four steps of SPE procedure.

\subsection{Classical SPE Sorbents}

During the analysis of antibiotics, the extraction and cleanup of target antibiotics from the matrix is an important step. From milk, antibiotics are most commonly isolated using liquid-liquid extraction (LLE) and SPE [36]. The isolation of low molecular mass basic compounds and neutral compounds can be accomplished using carboxy (CX) SPE cartridges and hydrophilic-lipophilic balance (HLB) SPE cartridges, respectively. A tandem SPE cleanup method using mixed cation exchange (MCX) and HLB cartridges compared with single cartridge methods provides significantly improved extraction efficiency with the recoveries of $94 \%$ vancomycin, $95 \%$ teicoplanin, $99 \%$ telavancin, $89 \%$ oritavancin, and $91 \%$ 
dalbavancin, as shown by Deng et al. in their studies for the detection of five glycopeptide antibiotics in milk [37]. Similarly, the extraction of polyether antibiotics including lasalocid, salinomycin, monensin, narasin, and nigericin residues in milk, chicken, chicken livers, and egg samples were performed with acetonitrile and purified by ENVI-Carb SPE columns with an average recovery of the analytes fortified at three levels ranged from $68.2 \%$ to $114.3 \%$ and limit of quantification (LOQ) obtained for milk and chicken was $0.4 \mu \mathrm{g} / \mathrm{kg}$, and for chicken livers and eggs, it was $1 \mu \mathrm{g} / \mathrm{kg}$ [33]. Among several cleanup cartridges, including HLB, ENVI-Carb, Silica, Neutral Alumina, and Florisil, ENVI-Carb was found to be the best SPE cartridge for cleaning up the extracts from milk, chicken, egg, and chicken liver. These cartridges were found to be efficient for removing background organic compounds and also reduced operation and sample preparation time [33]. Likewise, for the simultaneous determination of sulfonamides from fish, crab, and shrimp samples, ultrasonic extraction and liquid extraction of $n$-hexane was used, in which an online SPE cleanup equipped with a mixed cation exchange column (Oasis ${ }^{\circledR} \mathrm{MCX}$ ) connected with a hydrophilic-lipophilic balance column (Oasis ${ }^{\circledR} \mathrm{HLB}$ ) was used for sample pretreatment to remove interferences. As a result, the limit of detection (LOD) and LOQ obtained ranged from 1.46 to $15.5 \mathrm{ng} / \mathrm{kg}$, and 4.90 to $51.6 \mathrm{ng} / \mathrm{kg}$, respectively [38].

\subsection{New SPE Sorbents}

The sorbent is a critical component in determining the performance of SPE and several SPE sorbent materials, including metal-organic frameworks (MOFs), molecularly imprinted polymers, porous organic polymers (POPs), carbon nanotubes, electrospun nanofibers, magnetic nanocomposites, high internal phase emulsion polymers, and others were employed for the extraction of antibiotic residues from food samples [34,39,40]. Among POPs, porous covalent organonitridic frameworks (PCONFs) are an ideal sorbent for sulfonamide antibiotics as these sorbent materials possess high surface area and rich $\pi$-electron properties. This method, under optimized conditions, possesses the properties such as wide linear ranges $\left(2.5-1000 \mathrm{ng} \cdot \mathrm{L}^{-1}\right)$ and low limits of detection $\left(0.14-2.0 \mathrm{ng} \cdot \mathrm{L}^{-1}\right)$ [34]. The rapid extraction of sulfonamide residues (sulfacetamide, sulfadiazine, sulfathiazole, sulfapyridine, sulfamerazine, sulfamethazine, sulfamethoxazole, and sulfisoxazole) in chicken meat and milk was carried out using PCONFs as SPE sorbents and methanol as an eluting solvent, demonstrating the suitability of these materials for the enrichment of polar sulfonamides [34]. Likewise, for the extraction of tetracyclines in chicken, electrospun graphene oxide-doped poly (acrylonitrile-co-maleic acid) nanofibers (E-spun-GO/PANCA-NFs) was fabricated as a novel adsorbent for SPE, which exhibited good stability, large extraction capacity, and excellent extraction efficiency. The result of which provided limits of detection from 20.4 to $44.8 \mu \mathrm{g} / \mathrm{kg}$, and limits of quantification from 69.7 to $115.5 \mu \mathrm{g} / \mathrm{kg}$ [40]. Similarly, polyacrylonitrile@COFs (PAN@COF-SCU1) electrospun composite nanofibers were developed and used as an absorbent in pipette tip SPE (PT-SPE) for high-efficient extraction of tetracyclines in grass carp and duck samples in which LOD and LOQ were ranged from 0.6 to $3 \mathrm{ng} \mathrm{mL}^{-1}$ and 2 to $10 \mathrm{ng} \mathrm{mL}^{-1}$, respectively [41].

Since the widely used SPE cartridges are weak cation-exchange and hydrophiliclipophilic columns, molecularly imprinted polymers (MIPs) emerged recently as novel sorbents due to their selective extraction of target compounds as a result of strong interaction between MIPs and the target molecules [42]. Yang et al. proposed a method for simultaneous determination of 11 aminoglycoside residues, including amikacin, paromomycin, dihydrostreptomycin, gentamicin, hygromycin, kanamycin, netilmicin, spectinomycin, sisomicin, streptomycin, and tobramycin, in honey, milk, and pork samples using a Supel MIP SPE-Aminoglycoside cartridge, proving it to be powerful and selective material for the extraction and cleanup of antibiotics in complex food matrices. The method showed the LOD of $2-30 \mu \mathrm{g} / \mathrm{kg}$ and the LOQ of 7-100 $\mu \mathrm{g} / \mathrm{kg}$ with the average recovery ranged from 78.2 to $94.8 \%$ [43]. Similarly, the extraction of polyether ionophore antibiotic residues in milk, eggs, and poultry meat and liver was performed by preparing carbon-nanotube magnetic nanoparticles (CNT-MNPs) applied to magnetic solid-phase 
extraction (MSPE) [44]. It was demonstrated that these CNT-MNPs exhibited good extraction efficiencies for polyether ionophore antibiotics, and the method is green, low cost, and rapid [44]. Likewise, a variation to the MSPE method, namely, micro-solidphase extraction (M- $\mu-\mathrm{SPE})$, was developed by using TMCNTs (thiol-functionalized magnetic carbon nanotubes) as a sorbent and used for the extraction of four sulfonamides in milk, eggs, and chicken meat samples [45]. The method under optimized TMCNTs-M$\mu$-SPE and HPLC-DAD conditions showed good linearity in the range of $0.1-500 \mu \mathrm{g} \mathrm{L}{ }^{-1}$ $\left(\mathrm{r}^{2} \geq 0.9950\right)$, low limits of detection $\left(0.02-1.5 \mu \mathrm{g} \mathrm{L}^{-1}\right)$, good analytes recovery $(80.7-116.2 \%)$, and acceptable RSDs $(0.3-7.7 \%, \mathrm{n}[\mathrm{M} 1]=15)$. Since TMCNTs as a sorbent on M- $\mu$-SPE enable analytes to be extracted and preconcentrated within $30 \mathrm{~min}$, TMCNTs-M- $\mu-\mathrm{SPE}$ can be regarded as a convenient method for identification of SAs in food samples [45].

On the other hand, besides SPE, the extraction of nine sulfonamides from milk samples by using dispersive liquid-liquid microextraction (DLLME) and modified Quick, Easy, Cheap, Effective, Rugged, and Safe (QuEChERS) was reported; QuEChERS extraction was more reproducible while DLLME gave lower LOD values and higher recoveries of 90.8-104.7\% as compared to QuEChERS recoveries of 83.6-104.8\% [46]. The main steps of a typical QuEChERS procedure are shown in Figure 4. Moreover, the extraction of eight sulfonamides from butter samples was reported using an ionic liquid-magnetic bar-liquidphase microextraction (IL-MB-LPME) [47]. A large number of antibiotic residues from different food samples such as milk products (cheese, butter), honey samples, chicken meat, etc., could be extracted using various extraction methods, such as SPE, online SPE, MSPE, LLE, mini-SAE, and many more. A summary of the extraction of different antibiotics from various food products is depicted in Table 2.

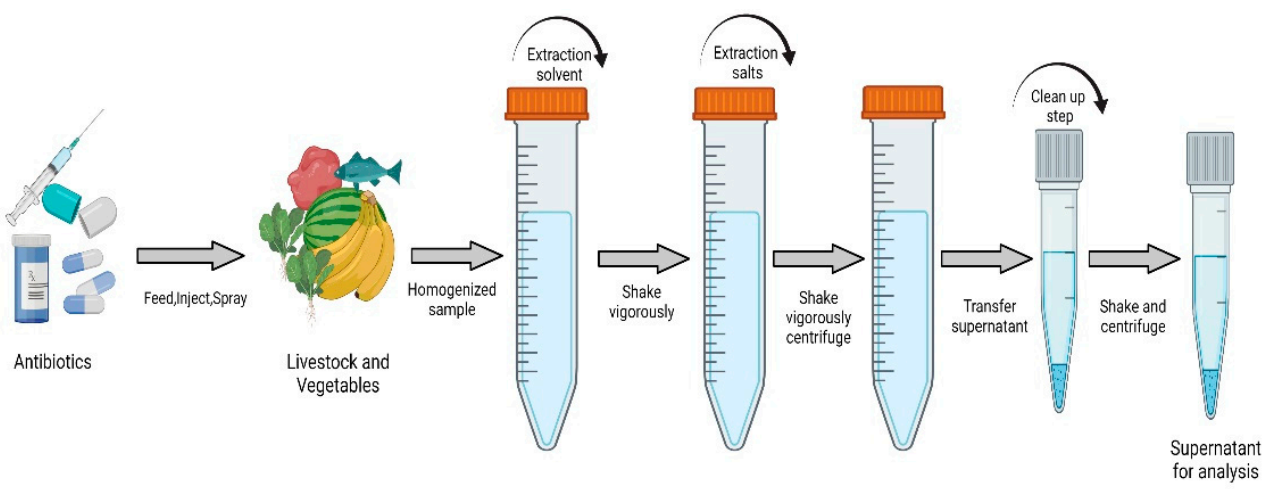

Figure 4. Schematic of a typical QuEChERS method.

Table 2. Extraction of antibiotics from different food samples.

\begin{tabular}{|c|c|c|c|c|c|c|c|c|}
\hline Analytes & Amount & Antibiotics & $\begin{array}{l}\text { Extraction } \\
\text { Methods }\end{array}$ & Adsorbent & Elution & $\begin{array}{l}\text { Separation } \\
\text { and } \\
\text { Detection }\end{array}$ & Year & References \\
\hline $\begin{array}{l}\text { Water, milk, } \\
\text { pork, and } \\
\text { fish }\end{array}$ & $\begin{array}{l}1 \mathrm{~L}, 250 \mathrm{~g}, \\
1000 \mathrm{~g} \text {, and } \\
500 \mathrm{~g}\end{array}$ & $\begin{array}{l}\text { Sulfonamide } \\
\text { antibiotics }\end{array}$ & $\begin{array}{l}\text { Magnetic } \\
\text { SPE }\end{array}$ & $\begin{array}{l}\mathrm{Fe}_{3} \mathrm{O}_{4} \\
@ \mathrm{MoS}_{2}\end{array}$ & $\begin{array}{l}\text { Methanol containing } \\
1 \% \text { ammonium } \\
\text { hydroxide }\end{array}$ & $\begin{array}{l}\text { HPLC- } \\
\text { MS/MS }\end{array}$ & 2020 & [48] \\
\hline $\begin{array}{l}\text { Water } \\
\text { and food }\end{array}$ & $5 g$ & $\begin{array}{l}\text { Quinolone } \\
\text { antibiotics }\end{array}$ & SPE & $\begin{array}{l}\text { TAPA-TFPB- } \\
\text { COFs }\end{array}$ & Methanol and water & LC-MS & 2020 & [49] \\
\hline Milk & $5 g$ & $\begin{array}{l}\text { Amoxicillin, } \\
\text { Ampicillin, } \\
\text { and Cloxacillin }\end{array}$ & Micro-SPE & $\begin{array}{l}\text { Starch-based } \\
\text { polymer }\end{array}$ & Methanol & HPLC-UV & 2019 & [50] \\
\hline Pork meat & $1 \mathrm{~g}$ & Macrolides & SPE & $\begin{array}{l}\text { Molecularly } \\
\text { imprinted } \\
\text { polymer }\end{array}$ & $\begin{array}{l}10 \% \text { acetic acid in } \\
\text { methanol. }\end{array}$ & LC-MS/MS & 2018 & [51] \\
\hline Chicken & $5.0 \mathrm{~mL}$ & Tetracyclines & SPE & $\begin{array}{l}\text { E-spun-GO- } \\
\text { PANCMANFs }\end{array}$ & $\begin{array}{l}\text { Ethanol/formic } \\
\text { acid/dichloromethane, } \\
40 / 20 / 40(v / v / v)\end{array}$ & HPLC-FLD & 2019 & [40] \\
\hline
\end{tabular}


Table 2. Cont

\begin{tabular}{|c|c|c|c|c|c|c|c|c|}
\hline Analytes & Amount & Antibiotics & $\begin{array}{l}\text { Extraction } \\
\text { Methods }\end{array}$ & Adsorbent & Elution & $\begin{array}{c}\text { Separation } \\
\text { and } \\
\text { Detection }\end{array}$ & Year & References \\
\hline $\begin{array}{l}\text { Honey and } \\
\text { milk }\end{array}$ & $\begin{array}{l}4 \mathrm{mg} \\
\text { and } \\
20 \mathrm{mg}\end{array}$ & $\begin{array}{c}\text { Oxytetracycline, } \\
\text { tetracycline, } \\
\text { Doxycyclin, } \\
\text { Cholrtetracy- } \\
\text { cline, } \\
\text { Methacycline }\end{array}$ & SPE & $\begin{array}{l}\text { Multiwalled } \\
\text { carbon } \\
\text { nanotubes }\end{array}$ & $\begin{array}{c}\text { Methanol and } \\
\text { double-distilled } \\
\text { water }\end{array}$ & $\begin{array}{c}\text { UPLC- } \\
\text { QTOF/MS }\end{array}$ & 2016 & [52] \\
\hline Honey & $100 \mathrm{~mL}$ & $\begin{array}{l}\text { Tetracycline, } \\
\text { cefotaxime }\end{array}$ & Micro-SPE & $\begin{array}{l}\text { Electrospun } \\
\text { graphene } \\
\text { oxide doped } \\
\text { polyethylene } \\
\text { terephtha- } \\
\text { late } \\
\text { nanofibers }\end{array}$ & Acetonitrile & HPLC-UV & 2018 & [53] \\
\hline Raw milk & $4.0 \mathrm{~mL}$ & $\begin{array}{l}\text { Tetracyclines, } \\
\text { Erythromycin, } \\
\text { Chlorampheni- } \\
\text { col }\end{array}$ & SPE & $\begin{array}{l}\text { Molecularly } \\
\text { imprinted } \\
\text { polymer }\end{array}$ & $\begin{array}{l}\text { Ethanol, methanol, } \\
\text { acetonitrile, and } \\
0.05 \% \text { ammonium } \\
\text { acetate solution }\end{array}$ & HPLC-ELSD & 2018 & [54] \\
\hline Milk & $1.0 \mathrm{~mL}$ & Tetracyclines & SPE & $\begin{array}{c}\text { Sep-Pak Vac } \\
\text { C18 } \\
\text { cartridges }\end{array}$ & Methanol & LVSS-CE & 2018 & [55] \\
\hline
\end{tabular}

Note: TAPA = Tris(4-aminophenyl)amine, TFPB = Tris(4-formylphenyl), COFs = Covalent organic frameworks, E-spun-GO-PANCMANFs = Electrospun graphene oxide-doped poly(acrylonitrile-co-maleic acid) nanofibers, SPE = Solid-phase extraction, HPLC = High Performance Liquid Chromatography, MS = Mass Spectrometry, UV = Ultraviolet Spectroscopy, LC = Liquid Chromatography, LVSS-CE = Large Volume Sample Stacking Capillary Electrophoresis, ELSD = Evaporative Light Scattering Detector, FLD-Fluorescence detection, UPLC-QTOF/MSultra-performance liquid chromatography/quadrupole time-of-flight mass spectrometry.

\section{Separation and Detection of Antibiotics}

\subsection{Chromatography}

Previously, paper chromatography and thin-layer chromatography were fundamental tools for the separation, identification, and quality control of antibiotics. Later advancements of modern technology such as High-Performance Liquid Chromatography (HPLC), Liquid Chromatography-Mass Spectrometry(LC-MS), Ultra-High Performance Liquid Chromatography (UHPLC), and others have revolutionized the separation and determination of different antibiotics in food and other biological samples $[38,49,56]$. Liquid chromatography coupled with mass spectrometry is being widely used in the detection of antibiotics [48,51]. However, the high cost of a mass spectrometer limits its use in small laboratories for routine analysis. As a result of which, the LC system coupled with other detectors, mainly ultraviolet (UV), diode array detector (DAD), and fluorescence detector (FLD), are considered as potential alternatives [51,57-59]. For antibiotics lacking a chromophore, an evaporative light scattering detector (ELSD) is being used [60]. Such detectors are used in the detection of polypeptide antibiotics, which showed better separation, narrower peaks, and little peak tailing as compared to the traditional C18 column [61].

\subsubsection{Column Selection}

For optimal detection of desired antibiotics in the sample, the LC column must be selected such that the compounds of interest should be separated. Under optimum conditions, the Kinetex Biphenyl column was utilized in the separation of the polypeptide antibiotics [61]. New columns based on the core-shell particle technology were found to be effective in reducing the chromatographic run time and improving the resolution; Kinetex C18 core-shell separated sulfonamides in less than 8 min in HPLC-UV/DAD method [57]. The utilization of cheaper Hypersil BDS C18 columns has helped in the separation and retention of aminoglycosides through utilizing ion-pair reagents [62,63]. A Poroshell 120 SB-C18 column showed the most effective separation effect and the highest response for total analytes for the separation of polypeptide antibiotics [64]. Figure 5 shows the differ- 
ent steps involved in the simultaneous determination of four polypeptide antibiotics in infant formula powder by using HPLC-MS/MS; the separation was carried out by using Poroshell 120 SC-C18 column.

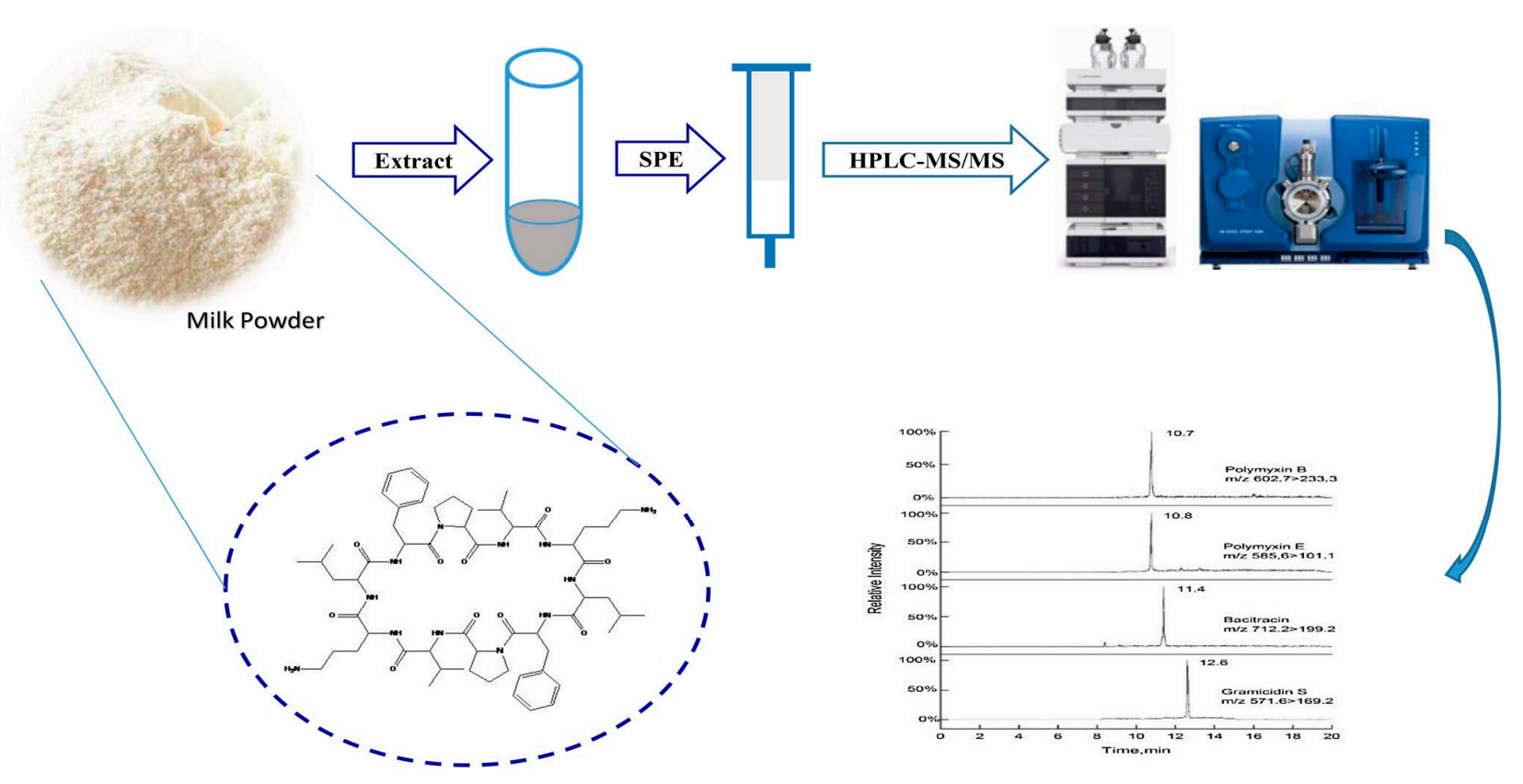

Figure 5. Simultaneous determination of four polypeptide antibiotics (polymyxin B, polymyxin E, bacitracin, and gramicidin S) in milk by HPLC-MS/MS (Reproduced with permission of the publisher) [64].

\subsubsection{Mobile Phase Selection}

The mobile phase used in the separation of antibiotics influences the detection in the chromatography. The additives and composition of the mobile phase were shown to influence the peak shape, resolution, and retention time of the compounds as well as the ionization efficiency of the compounds, which in turn, would affect the detection sensitivity of the analytes [65]. Methanol, acetonitrile (ACN), formic acid (FA), etc., are the most common mobile phases used in the separation of different antibiotics. Both methanol and ACN are a common choice as the mobile phase; methanol is cheaper and shows enhanced solubility of analytes which improves analytes detection, while acetonitrile shortened the analysis time and maintained the resolution of the entire components of the analytes $[63,66]$. Wang et al. used methanol or ACN with formic acid or acetic acid as an organic phase and water with formic acid as an aqueous phase for the separation of sulfonamides, quinolones, nitroimidazoles, pleuromutilins, and $\beta$ - lactams. Additionally, it was demonstrated that the use of ACN provides better peak shapes, whereas the use of methanol provides better separation [65]. Similarly, the use of additives such as formic acid and ammonium acetate greatly improves the resolution for some classes of compounds, for example, between sulfonamides and impurities, due to which the quantification of antibiotics under optimized conditions is possible using HPLC-UV methods [58]. For the separation of polypeptide antibiotics, formic acid is used as an additive in the mobile phase, which improves the separation as formic acid not only increases the acidity but also provides protons to improve the ionization efficiency in HPLC-MS/MS [64]. Moreover, formic acid used in gradient elution mode for the separation of sulfonamides with similar polarity helps in obtaining chromatographic peaks with no interference in Ultra-High Performance Liquid Chromatography (UHPLC) [38].

Along with this, different buffers (ammonium acetate and ammonium formate) are used for maintaining acidic $\mathrm{pH}$, which not only generates high chromatographic resolution but also results in improved ionization efficiency and signal intensity in LC-MS/MS [62]. In reversed-phase liquid chromatography, tetracyclines were found to give broad and 
unsymmetrical peaks due to ionic interactions of these analytes with ionic free silanol groups and metal ions present in the silica-based stationary columns, and these frequently observed limitations were solved by using methanesulfonic acid as an eluent additive; the acid neutralizes the anionic silanol sites and electrostatic attractions with analytes [66]. Accordingly, heptafluorobutyric acid (HFBA) was used as an ion-pair reagent in the mobile phase to form an ion-pair complex with aminoglycosides to retain well in the reverse phase chromatographic column in High-Performance Liquid Chromatography-Evaporative Light Scattering Diode (HPLC-ELSD) [63]. The major challenges during the detection of antibiotics using the chromatographic technique are matrix interferences, polar differences, and the low concentration of antibiotics in food samples $[38,66,67]$. Therefore, to assess the effectiveness of the proposed method, the right analytical technique must be selected. A summary of the detection of antibiotics using chromatographic techniques is shown in Table 3.

Table 3. Detection of antibiotics using different chromatographic methods.

\begin{tabular}{|c|c|c|c|c|c|c|c|c|c|}
\hline Analytes & Antibiotics & $\begin{array}{l}\text { Detection } \\
\text { Methods }\end{array}$ & $\begin{array}{l}\text { Extraction } \\
\text { Methods }\end{array}$ & Mobile Phase & $\begin{array}{c}\text { Stationary } \\
\text { Phase }\end{array}$ & LOD & Year & $\begin{array}{c}\text { Recovery } \\
(\%)\end{array}$ & References \\
\hline \multirow{2}{*}{$\begin{array}{c}\text { Fish, } \\
\text { shrimp, } \\
\text { and crab }\end{array}$} & \multirow[t]{2}{*}{ Sulfonamides } & \multirow[t]{2}{*}{$\begin{array}{l}\text { UHPLC- } \\
\text { MS/MS }\end{array}$} & \multirow[t]{2}{*}{ On-line SPE } & $\begin{array}{l}\text { (1) } 0.1 \% \text { formic } \\
\text { acid in water }\end{array}$ & \multirow{2}{*}{$\begin{array}{l}\text { C18 } \\
\text { pentafluo- } \\
\text { rophenyl } \\
\text { (F5 or PFP) } \\
\text { column }\end{array}$} & $\begin{array}{c}0.00146- \\
0.0155 \\
\mathrm{ng} / \mathrm{mL}\end{array}$ & \multirow[t]{2}{*}{2020} & \multirow[t]{2}{*}{ 71.5-102 } & \multirow[t]{2}{*}[38]{} \\
\hline & & & & $\begin{array}{l}\text { (2) } 0.1 \% \text { formic } \\
\text { acid in ACN }\end{array}$ & & $\begin{array}{c}0.00490- \\
0.0516 \\
\mathrm{ng} / \mathrm{mL}\end{array}$ & & & \\
\hline
\end{tabular}

\begin{tabular}{|c|c|c|c|c|c|c|c|c|c|}
\hline Eggs & $\begin{array}{l}\text { Sulfonamides, } \\
\text { quinolones, } \\
\text { tetracyclines, } \\
\text { macrolides, } \\
\text { lincosamide, } \\
\text { nitrofurans, } \\
\beta \text {-lactams, } \\
\text { nitromidazoles, } \\
\text { and cloram- } \\
\text { phenicols }\end{array}$ & $\begin{array}{c}\mathrm{LC}- \\
\mathrm{MS} / \mathrm{MS}\end{array}$ & HILIC-SPE & $\begin{array}{l}(1) \mathrm{H} 2 \mathrm{O} \text { and } \\
\mathrm{ACN}, \\
(2) \mathrm{H}_{2} \mathrm{O} \text { and } \\
\mathrm{ACN} \\
\text { containing0.1\% } \\
\text { formic }\end{array}$ & $\begin{array}{c}\text { Poroshell } \\
120 \text { EC-C18 } \\
\text { column }\end{array}$ & $\begin{array}{l}0.005-2.00 \\
\mathrm{ng} / \mathrm{mL}\end{array}$ & 2017 & $\begin{array}{l}70.8- \\
116.1\end{array}$ & [68] \\
\hline $\begin{array}{l}\text { Animal } \\
\text { feed }\end{array}$ & Cyclopolypeptide & $\begin{array}{l}\text { HPLC- } \\
\text { ELSD }\end{array}$ & On-line SPE & $\begin{array}{l}\text { Methanol and } \\
\text { ammonium } \\
\text { acetate aqueous } \\
\text { solution } \\
\text { containing } \\
\text { formic acid (B) }\end{array}$ & $\begin{array}{l}\text { Kinetex } \\
\text { Biphenyl } \\
\text { column }\end{array}$ & $2-5 \mu \mathrm{g} / \mathrm{mL}$ & 2018 & $\begin{array}{l}72.0- \\
105.4\end{array}$ & [61] \\
\hline Eggs & $\begin{array}{l}\text { Sulfonamides, } \\
\text { quinolones, } \\
\text { pleuromutilins, } \beta \text { - } \\
\text { lactams }\end{array}$ & $\begin{array}{l}\text { UHPLC- } \\
\text { MS/MS }\end{array}$ & $\begin{array}{c}\text { Dispersive } \\
\text { SPE }\end{array}$ & $\begin{array}{c}0.1 \% \text { FA and } \\
\text { MeOH:ACN,2:8, } \\
\text { v/v, containing } \\
0.1 \% \text { FA }\end{array}$ & $\begin{array}{l}\text { BEH C18 } \\
\text { column }\end{array}$ & $\begin{array}{c}0.1-1 \\
\mathrm{ng} / \mathrm{mL}\end{array}$ & 2021 & $\begin{array}{l}70.5- \\
119.2\end{array}$ & [65] \\
\hline $\begin{array}{l}\text { Animal } \\
\text { feeds }\end{array}$ & Aminoglycosides & $\begin{array}{l}\text { HPLC- } \\
\text { ELSD }\end{array}$ & $\begin{array}{c}\text { Dispersive } \\
\text { SPE }\end{array}$ & $\begin{array}{l}\text { Acetonitrile } \\
\text { and water }\end{array}$ & $\begin{array}{l}\text { Hypersil } \\
\text { BDS C18 }\end{array}$ & $\begin{array}{c}0.2-0.7 \\
\mu \mathrm{g} / \mathrm{mL}\end{array}$ & 2017 & $\begin{array}{l}61.2- \\
104.0\end{array}$ & [63] \\
\hline $\begin{array}{c}\text { Foods of } \\
\text { animal } \\
\text { origin }\end{array}$ & Sulfonamides & HPLC-UV & Centrifugation & $\begin{array}{l}\text { Mixtures of } \\
\text { acetonitrile, } \\
\text { water, formic } \\
\text { acid, and } \\
\text { ammonium }\end{array}$ & $\begin{array}{l}\text { Inertsil } \\
\text { ODS-3 }\end{array}$ & $\begin{array}{l}6.5-11.0 \\
\mathrm{ng} / \mathrm{mL}\end{array}$ & 2018 & $85-95$ & [58] \\
\hline Milk & Sulfonamides & $\begin{array}{c}\text { HPLC/UV- } \\
\text { DAD }\end{array}$ & Centrifugation & $\begin{array}{c}\text { Acetate buffer } \\
\text { solution at } \mathrm{pH} \\
4.50 \text { and } \mathrm{a} \\
\text { mixture of } \\
\text { methanol } \\
\text { acetonitrile } \\
50: 50(v / v)\end{array}$ & $\begin{array}{c}\text { C18 } \\
\text { column }\end{array}$ & $\begin{array}{r}2.7-15 \\
\mathrm{ng} / \mathrm{mL}\end{array}$ & 2018 & $55-86$ & [57] \\
\hline
\end{tabular}

Note: UHPLC = Ultra-High Performace Liquid Chromatography, MS = Mass Spectrometry, LC = Liquid Chromatography, HILIC-SPE = Hydrophilic Solid-Phase Extraction, ELSD = Evaporative Light Scattering Detection, ESI = Electro Spray Ionization, UV-DAD = UV-Diode Array Detection. 


\subsection{Capillary Electrophoresis}

The chromatographic techniques require excess solvent, more time for sample preparation, and different types of stationary phases, which make the techniques more cumbersome in laboratories with limited resources $[67,69]$. Capillary electrophoresis (CE) is cost-effective, is simple to operate, consumes fewer reagents, and provides high separation efficiency; this technique was widely employed in the separation and detection of antibiotics in a wide range of food samples. The performance of $\mathrm{CE}$ can be improved by various means, such as changing buffer type, $\mathrm{pH}$, voltage, mode of the $\mathrm{CE}$, etc. [70,71]. Similarly, various preconcentration techniques were employed to enhance the sensitivity in CE. Apart from these, injection techniques were modified to optimize the CE [72].

$\mathrm{CE}$ optimization can be achieved through maintaining buffer type, $\mathrm{pH}$, and voltage [73]. Buffer composition not only enhances the separation but also improves the electrophoretic characteristics of the target analytes; when electrolytes are mixed with phosphate and borate, complex formation between borate anions (tetrahydroxyborate) and tetracyclines occurs, resulting in the modification of electrophoretic characteristics and thereby separation of tetracyclines [74]. With an increase in the buffer concentration under the combined influence of the electro-osmotic flow and the electrophoretic force, the separation of the sulfonamides in the milk sample was improved. However, with the increase in the buffer concentration above optimum concentration, friction between the buffer and the inner capillary wall increased. As a result, the temperature of the column increased, resulting in the broadening of the peaks and reduction in the capillary lifetime [74,75]. It was found that the migration rate and chemiluminescence signals of sulfonamides were affected by the concentration of sodium borate buffer, and the signal intensity was found to be inversely proportional to the buffer concentration [76]. Figure 6 depicts the synthesis of PEG@MoS2 and its application in the determination of eight sulfonamides in milk samples by dispersive solid-phase extraction (DSPE)-Capillary zone electrophoresis (CZE).

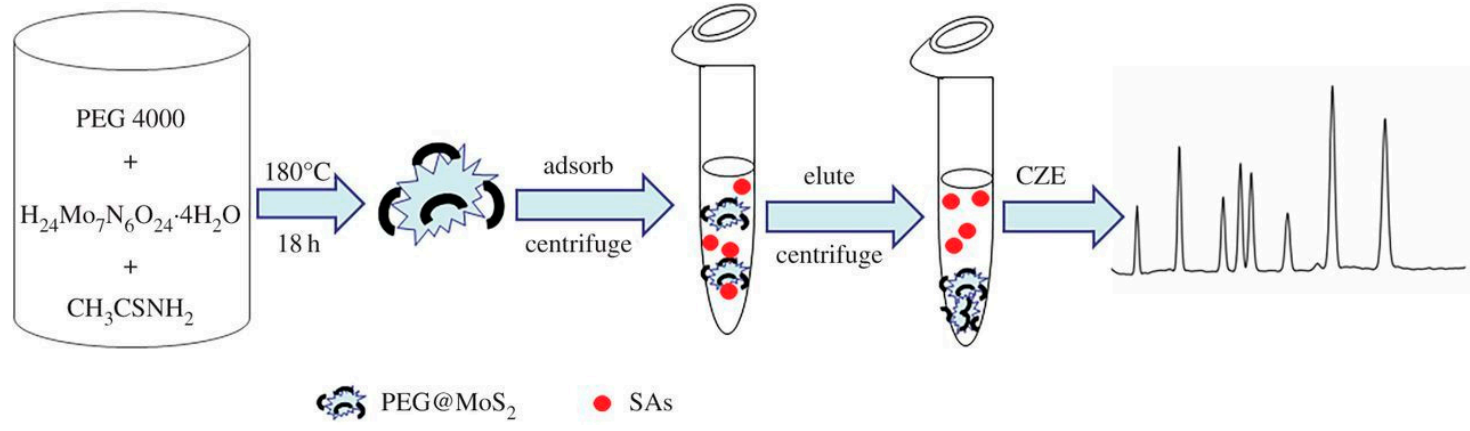

Figure 6. Schematic illustration of detection of eight sulfonamides by using DSPE-CZE [75] (Reproduced with permission of the publisher).

In $\mathrm{CE}$, the $\mathrm{pH}$ value of the running buffer plays an important role in the separation of analytes. In the separation of tetracyclines and quinolones, a basic condition was maintained using ammonium acetate and ammonium carbonate buffers at $\mathrm{pH} 9.0$ as the basic condition was found to be suitable for effective separation of these antibiotics [73]. It was also demonstrated that with an increase in $\mathrm{pH}$, the separation between sulfadiazine and sulfachlorpyridazine first increased and then decreased, with the optimum $\mathrm{pH}$ for separation being 7.26 [75]. Similarly, the $\mathrm{pH}$ of the running buffer at about 9.5 was found to provide good separation of sulfamethazine, sulfadiazine, and sulfathiazole [76].

The effect of $\mathrm{pH}$ was significant in the separation of five macrolides from a milk sample; when the $\mathrm{pH}$ is less than 6.5, erythromycin and clarithromycin somewhat overlap. However, when the $\mathrm{pH}$ is greater than 8.0, tylosin almost completely overlaps the negative solvent peak, making it difficult to detect [77]. The baseline separation of macrolides was accomplished when the $\mathrm{pH}$ was between 6.5 and 7.5; in addition, the shortest migration time and the best peak shape were achieved at pH 7 [77]. Similarly, the applied voltage is 
another factor that affects the separation of analytes in CE; for example, adequate separation of fluoroquinolones was observed at an applied voltage of $20 \mathrm{kV}$ [78]. It should be noted that the voltage applied on a certain range is better for the separation because higher voltage increases Joule heating, which represses the capillary efficiency and viscosity of the running buffer [78].

Detectors are a key component in CE, and an efficient combination of the separation capillary and a detector is required for the optimal detection of separated analytes. For effective detection of analytes using $\mathrm{CE}$, the capillary was combined with various detectors such as a mass spectrometer, UV detector, light-emitting diode, etc. [73,75]. The CZE coupled with ion trap mass analyzer (for MS/MS analysis) was developed as an alternative to LC-MS/MS for the separation and detection of twelve benzimidazoles in meat samples [79]. Employing MS/MS as a detection system improves the selectivity and sensitivity of CE analysis [79]. Similarly, graphene quantum dots (GQDs) were used to enhance the sensitivity of $\mathrm{CE}$ with fluorescence detectors for the quantitative determination of ofloxacin in milk samples [78]. Sensitivity was determined in the presence and absence of GQDs, and a significant enhancement in sensitivity was observed when GQDs are injected into the capillary before sample loading [78]. Interestingly, it was observed that the GQDs enhance the photoluminescence of hydrophobic antibiotics, such as lomefloxacin, norfloxacin, and ofloxacin, an aqueous medium [78]. Moreover, a low-cost microchip CE system containing an electrophoresis chip and fluorescence detector was constructed for the determination of ciprofloxacin in milk samples [80]. Apart from these, CZE using online chemiluminescence (CL) detector and CE-UV detector were used for the detection of the sulfonamides and fluoroquinolones, respectively, in food samples [76,81]. Figure 7 depicts the schematic representation of CZE with an online chemiluminescence detector.

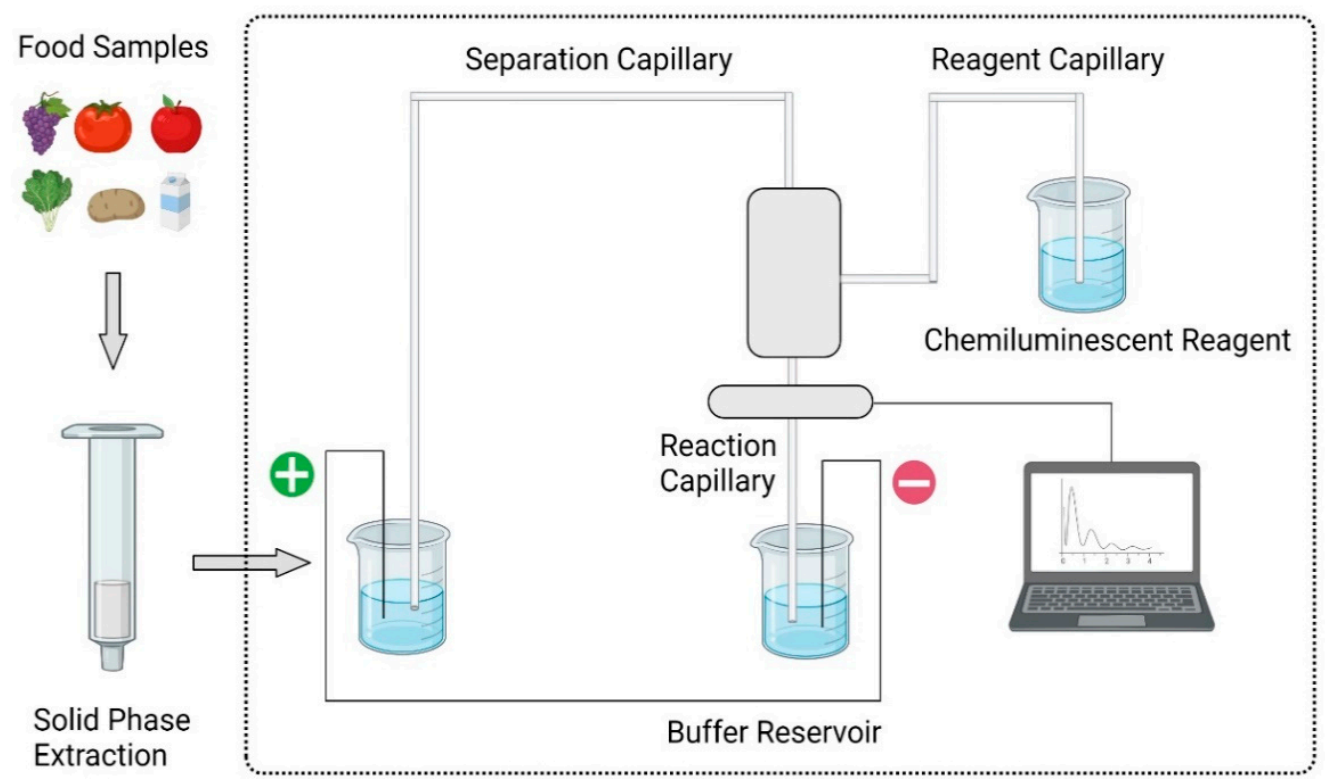

Figure 7. Schematic representation of CZE with chemiluminescence detection.

CE was used in various modes as per the need for samples to improve the separation and detection of antibiotics. Among various techniques, field amplified sample injectioncapillary zone electrophoresis (FASI-CZE) is an operation mode in which the sample is preconcentrated in a capillary as an effect of amplified electricity between a sample and a running buffer [74]. While performing preconcentration of samples, it was found that the greater the contrast between the buffer conductivity and the sample, the better the preconcentration of the analytes of interest [74]. Similarly, electrokinetic injection (EKI) and pressure-assisted electrokinetic injection (PAKEI) were employed as online preconcentration techniques in $\mathrm{CE}$ for the effective stacking of anionic analytes. In the case of PAKEI, during injection, the velocity of electro-osmotic flow (EOF) is counterbalanced 
by the external pressure, thereby creating a stationary boundary between the sample zone and background electrolyte (BGE) at the capillary inlet due to which a large number of analytes are introduced into the capillary [70]. The different parameters and analytical performance of the CE-based methods for the analysis of different antibiotics in food samples are summarized in Table 4.

Table 4. Detection of different antibiotics in foods using capillary electrophoresis methods.

\begin{tabular}{|c|c|c|c|c|c|c|c|c|c|}
\hline Analytes & Antibiotics & $\begin{array}{l}\text { Extraction } \\
\text { Methods }\end{array}$ & Buffer & $\mathrm{pH}$ & $\begin{array}{l}\text { Limits of } \\
\text { Detec- } \\
\text { tion }\end{array}$ & $\begin{array}{c}\text { Voltage } \\
(\mathrm{kV})\end{array}$ & $\begin{array}{l}\text { Recovery } \\
(\%)\end{array}$ & Year & Reference \\
\hline Milk & Oxytetracycline & SPME & $\begin{array}{c}\text { Sodium } \\
\text { phosphate }+ \\
\text { EDTA } \\
\text { disodium salt } \\
+5 \% \text { 2-propanol }\end{array}$ & 12 & $\begin{array}{c}0.07 \\
\mu \mathrm{g} / \mathrm{mL}\end{array}$ & 14 & - & 2019 & [72] \\
\hline Milk & $\begin{array}{l}\text { Tetracyclinesand } \\
\text { Quinolones }\end{array}$ & SPE & $\begin{array}{l}\text { Mcllvaine's } \\
\text { buffer }\end{array}$ & 9.0 & $\begin{array}{l}0.5-2.9 \\
\mathrm{ng} / \mathrm{mL}\end{array}$ & 25 & $72.6-105.8$ & 2017 & [73] \\
\hline Milk & Sulfonamides & DSPE & $\begin{array}{c}\text { Phosphate } \\
\text { buffer }\end{array}$ & 7.26 & $\begin{array}{c}0.03-0.20 \\
\mu \mathrm{g} / \mathrm{mL}\end{array}$ & 18 & $\begin{array}{l}60.52- \\
110.91\end{array}$ & 2018 & [75] \\
\hline $\begin{array}{l}\text { Milk, pork, } \\
\text { and } \\
\text { chicken }\end{array}$ & Sulfonamide & SPE & $\begin{array}{l}\text { Sodium borate } \\
\text { buffer }\end{array}$ & 9.5 & $\begin{array}{c}0.65-3.14 \\
\mu \mathrm{g} / \mathrm{mL}\end{array}$ & 18 & $79.5-112.4$ & 2017 & [76] \\
\hline \multirow[t]{2}{*}{ Water } & \multirow{2}{*}{$\begin{array}{l}\text { Fluoroquinolones } \\
\text { and } \\
\text { sulfonamides }\end{array}$} & \multirow[t]{2}{*}{ DLLME } & \multirow[t]{2}{*}{ Borate buffer } & \multirow[t]{2}{*}{10} & $\begin{array}{c}1.96 \\
\mathrm{ng} / \mathrm{mL}\end{array}$ & \multirow[t]{2}{*}{15} & \multirow[t]{2}{*}{$83.3-98.7$} & \multirow[t]{2}{*}{2019} & \multirow[t]{2}{*}[70]{} \\
\hline & & & & & $\begin{array}{c}4.06 \\
\mathrm{ng} / \mathrm{mL}\end{array}$ & & & & \\
\hline \multirow[t]{3}{*}{ Milk } & \multirow[t]{3}{*}{ Macrolides } & \multirow[t]{3}{*}{$\begin{array}{l}\text { Ultrasonic } \\
\text { and cen- } \\
\text { trifugation }\end{array}$} & \multirow[t]{3}{*}{$\begin{array}{l}\text { Phosphate+ } \\
\text { sodium } \\
\text { cholate+ } \\
\text { cetyltrimethy- } \\
\text { lammonium } \\
\text { bromide }\end{array}$} & \multirow[t]{3}{*}{7.0} & $\begin{array}{c}0.002- \\
0.004 \\
\mu \mathrm{g} / \mathrm{mL}\end{array}$ & \multirow[t]{3}{*}{10} & \multirow[t]{3}{*}{$72.8-93.7$} & \multirow[t]{3}{*}{2018} & \multirow[t]{3}{*}[77]{} \\
\hline & & & & & $2 \mathrm{ng} / \mathrm{mL}$ & & & & \\
\hline & & & & & $4 \mathrm{ng} / \mathrm{mL}$ & & & & \\
\hline Milk & Ofloxacin & MEP & $\begin{array}{l}\text { sodium tetrabo- } \\
\text { rate+SDS+ } 10 \% \\
(v / v) \text { methanol }\end{array}$ & 7.5 & $\begin{array}{c}1.07 \\
\mathrm{ng} / \mathrm{mL}\end{array}$ & 20 & - & 2019 & [78] \\
\hline Meat & Benzimidazoles & DLLME & Formic acid & 2.2 & $\begin{array}{l}>0.003 \\
\mu g / \mathrm{mL}\end{array}$ & 20 & $70.1-95.5$ & 2017 & [79] \\
\hline
\end{tabular}

Note: HPLC = High Performance Liquid Chromatography, SPE = Solid-Phase Extraction, MS = Mass Spectrometry, MSPE = Magnetic SolidPhase Extraction, DLLME = Dispersive Liquid-Liquid Micro Extraction, PLE = Pressurized Liquid Extraction, LC = Liquid Chromatography, PMME $=$ Polymer Monolith Micro Extraction, $\mathrm{SPME}=$ Solid-phase micro-extraction, $\mathrm{MEP}=$ Microextraction by packed solvent, $\mathrm{DSPE}=$ Dispersive solid-phase extraction.

\subsection{Immunological Methods}

Chromatographic and CE-based methods are specific, accurate, and can be used for simultaneous determination of multiple antibiotics; however, these methods are limited by high instrumental cost and long and complicated procedures due to which on-site detection of antibiotics is not possible. Immunological assays, on the other hand, are simple, highly selective, rapid, and cost-effective; thus, they can be used for the on-site detection of antibiotics [81]. Enzyme-linked immunosorbent assay (ELISA), indirect complete ELISA (ic-ELISA), fluorescence polarization immunoassay (FPIA), immunochromatographic assay (ICA), etc., are various immunological techniques currently in use [82-85]. The principle of the immunoassays for the detection of antibiotics is shown in Figure 8.

The antibody is the most important factor for the development of efficient immunological assays. Immunoglobulin $\mathrm{G}(\mathrm{IgG})$-derived antibodies from rabbit and mouse was traditionally used for the development of immunoassays. Recently, there were several 
studies in the use of immunoglobulin Y (IgY), a chicken egg yolk antibody, as a superior alternative to IgG. Liang et al. compared under parallel conditions to know the sensitivity, specificity, and matrix effects in the detection of sulfamethazine in milk samples and found that $\operatorname{IgY}$ can be an alternative to IgG for the detection of antibiotic residues in food products [86]. Similarly, Li et al. evaluated immunoglobulin Y (IgY) using FPIA and ic-ELISA to detect gentamicins/kanamycin and found that the LOD and IC ${ }_{50}$ values for the ic-ELISA are better than FPIA, which indicated the suitability of ic-ELISA over FPIA for detecting antibiotics in animal-derived samples [83].

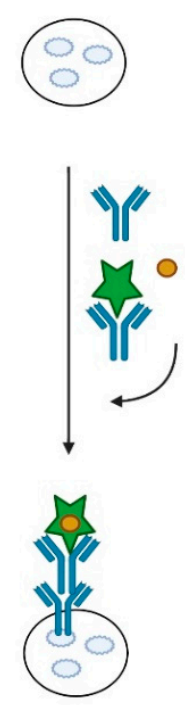

A. ELISA
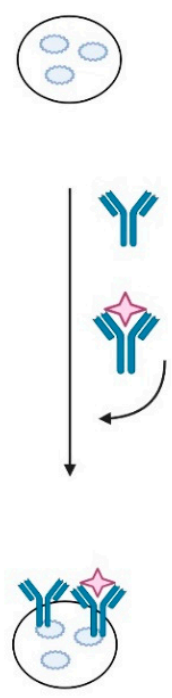

B. FPIA

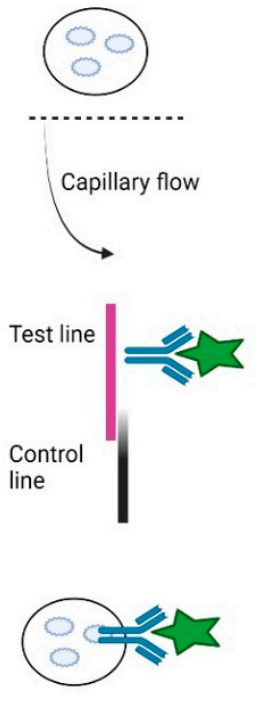

C. ICA

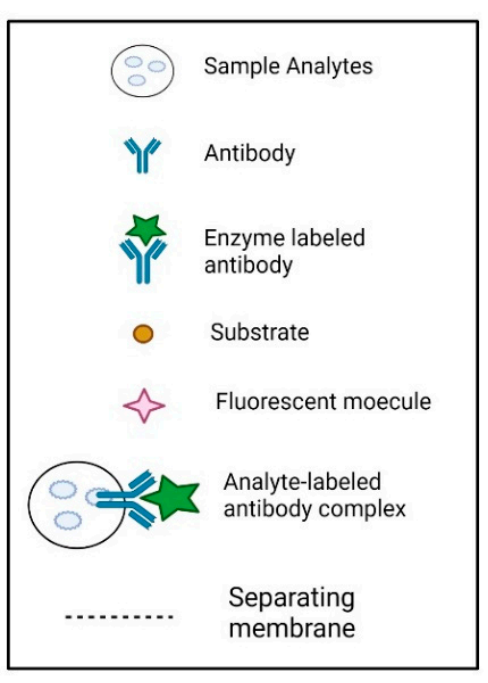

Figure 8. Schematic representation for detection of antibiotics by immunoassay methods.

Moreover, the use of monoclonal antibodies (mAbs) has widened the scope of the immunological assays; Li et al. developed an ultra-high sensitive ic-ELISA based on the broad-specificity $\mathrm{mAbs}$ for simultaneous detection of five antibacterial synergists (trimethoprim, diaveridine, brodimoprim, ormetoprim, and baquiloprim) in chicken and milk samples [83]. The traditional ELISA requires a time-consuming multi-step separation process, and to overcome this limitation, fluorescence polarization immunoassay (FPIA) was developed, which obviates the need for a separation step [87].

A simple fluoroimmunoassay was developed to detect tetracyclines, in which the receptor of tetracyclines, Tet repressor protein (TetR), was directionally mutated to produce two mutants that exhibited high affinity and high sensitivity for the detection of tetracyclines; the mutants were combined with fluorescence-labeled tracers for simultaneous detection of nine tetracyclines in egg samples [88]. The assay process of the Tet repressor protein (TetR) mutant-based fluoroimmunoassay for the detection of antibiotics is shown in Figure 9.

Similarly, a magneto immunofluorescence assay was developed to improve the selectivity and sensitivity of immunoassays; the use of magnetic beads (MB) combined with antigens or antibodies provides more surface area for efficient capture of target analytes [82]. Kergaravat et al. found a competitive step between free quinolones in samples and immobilized quinolones on MB for anti-quinone antibody (Ab1), as a result of which non-specific adsorption was reduced, thereby minimizing matrix effects [82]. The structure of a tracer could greatly influence the performance of a fluorescence polarization immunoassay; a heterologous tracer is recognized weakly by an antibody than a homologous tracer so that a heterologous tracer provides higher sensitivity than a homologous tracer. Considering this is a highly sensitive fluorescence polarization immunoassay, it was designed for the detection of clinafloxacin in goat milk [89]. Moreover, immunochromatographic assay (ICA) was developed employing time-resolved fluorescent nanobeads (TRFN) as a label for ultrasensitive detection of sulfamethazine in egg, honey, and pork samples; the accuracy 
of this assay was confirmed by the use of HPLC-MS /MS [85]. For the detection of fluoroquinolone, anti-pefloxacin (PEF)-monoclonal antibody (mAb), ic-ELISA, and lateral flow test strips were developed, and it was demonstrated that the methods based on ic-ELISA and lateral flow test strips are capable of sensitive and simultaneous detection of nine fluoroquinolones in chicken muscle samples [90]. Various immunological methods and their analytical performance for the detection of antibiotics in food samples are summarized in Table 5.

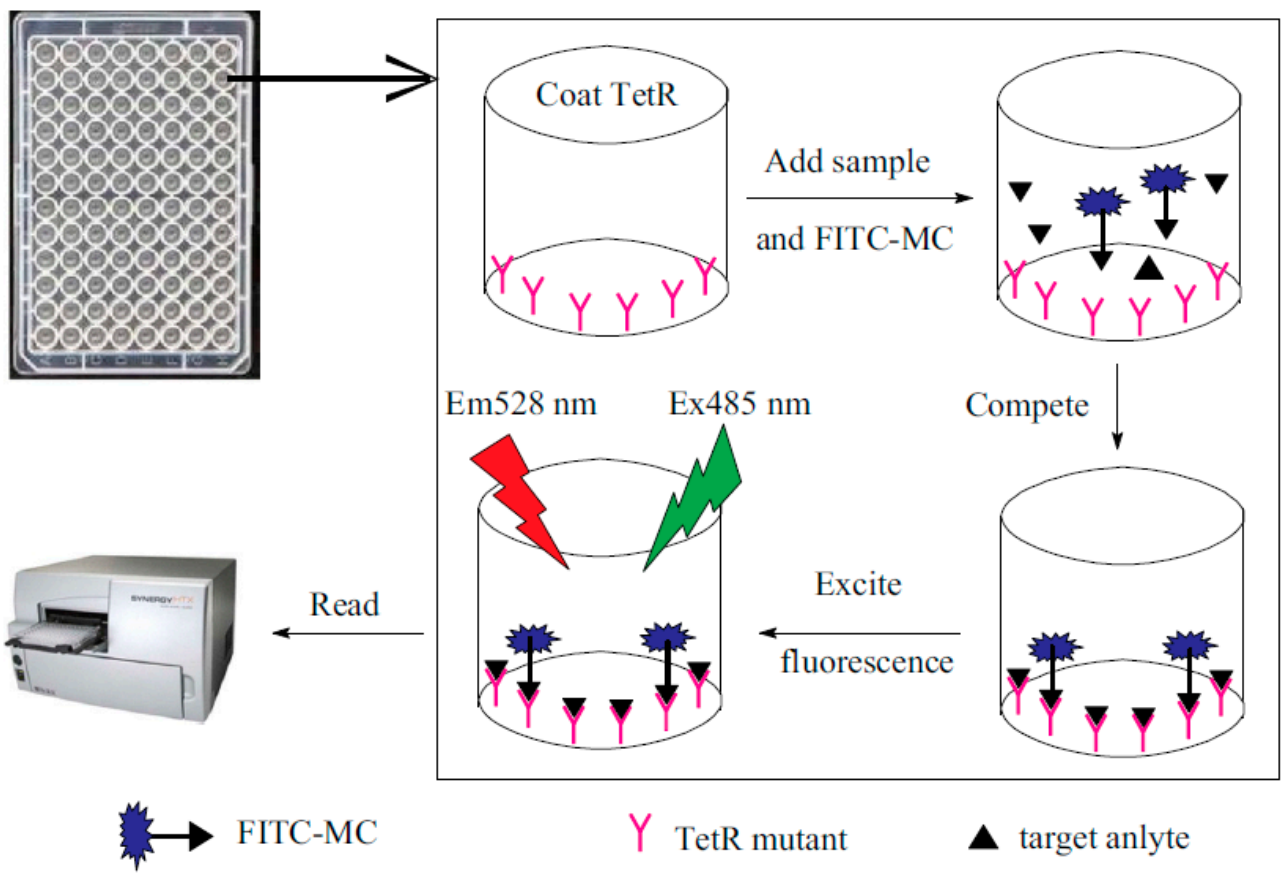

Figure 9. Schematic of the assay process of the Tet repressor protein (TetR) mutant based fluoroimmunoassay for the detection of antibiotics (Reproduced with permission of the publisher) [88].

Table 5. Detection of antibiotics by immunological methods.

\begin{tabular}{|c|c|c|c|c|c|c|c|c|}
\hline Analytes & Antibiotics & Detection & Extraction & $\mathrm{IC}_{50}$ & LOD & $\begin{array}{c}\text { Recovery } \\
(\%)\end{array}$ & Year & References \\
\hline \multirow[b]{2}{*}{ Milk } & \multirow[b]{2}{*}{ Sulfamethazine } & \multirow{2}{*}{$\begin{array}{l}\text { ic-ELISA } \\
\text { FPIA }\end{array}$} & \multirow{2}{*}{$\begin{array}{l}\text { Centrifugation } \\
\text { and dilution }\end{array}$} & $\begin{array}{l}6.70 \mathrm{ng} / \mathrm{mL} \\
4.76 \mathrm{ng} / \mathrm{mL} \\
1.66 \mathrm{ng} / \mathrm{mL}\end{array}$ & & $86.1-131.8$ & \multirow[b]{2}{*}{2018} & \multirow[b]{2}{*}[86]{} \\
\hline & & & & $\begin{array}{l}25.29 \mathrm{ng} / \mathrm{mL} \\
23.92 \mathrm{ng} / \mathrm{mL} \\
10.60 \mathrm{ng} / \mathrm{mL}\end{array}$ & & $81.8-120.2$ & & \\
\hline \multirow{4}{*}{$\begin{array}{l}\text { Animal- } \\
\text { derived } \\
\text { food }\end{array}$} & \multirow[t]{2}{*}{ Gentamicins } & \multirow[t]{2}{*}{$\begin{array}{c}\text { FPIA } \\
\text { ic-ELISA }\end{array}$} & \multirow{4}{*}{$\begin{array}{c}\text { PEG } \\
\text { precipitation }\end{array}$} & $\begin{array}{c}7.70 \pm 0.6 \\
\mu \mathrm{g} / \mathrm{mL}\end{array}$ & $\begin{array}{c}0.17 \\
\mu \mathrm{g} / \mathrm{mL}\end{array}$ & & & \\
\hline & & & & $\begin{array}{c}0.32 \pm 0.06 \\
\mu \mathrm{g} / \mathrm{mL}\end{array}$ & $\begin{array}{c}0.001 \\
\mu \mathrm{g} / \mathrm{mL}\end{array}$ & & & \\
\hline & \multirow[t]{2}{*}{ Kanamycin } & \multirow{2}{*}{$\begin{array}{c}\text { FPIA } \\
\text { ic-ELISA }\end{array}$} & & $\begin{array}{c}7.97 \pm 0.9 \\
\mu \mathrm{g} / \mathrm{mL}\end{array}$ & $\begin{array}{c}0.007 \\
\mu \mathrm{g} / \mathrm{mL}\end{array}$ & & 2017 & [83] \\
\hline & & & & $\begin{array}{c}0.15 \pm 0.01 \\
\mu \mathrm{g} / \mathrm{mL}\end{array}$ & $\begin{array}{c}0.001 \\
\mu \mathrm{g} / \mathrm{mL}\end{array}$ & & & \\
\hline Egg yolk & Gentamicins & ic-ELISA & Centrifugation & $2.69 \mathrm{ng} / \mathrm{mL}$ & $\begin{array}{c}0.01 \\
\mathrm{ng} / \mathrm{mL}\end{array}$ & $-\cdots$ & 2016 & [91] \\
\hline $\begin{array}{l}\text { Pork and } \\
\text { chicken }\end{array}$ & Enrofloxacin & FPIA & Centrifugation & $21.49 \mathrm{ng} / \mathrm{mL}$ & $\begin{array}{c}1.68 \\
\mathrm{ng} / \mathrm{mL}\end{array}$ & $91.3-112.9$ & 2019 & [87] \\
\hline Egg & Tetracyclines & Fluoroimmunoassay & Centrifugation & $\begin{array}{l}3.1-17.2 \\
\mathrm{ng} / \mathrm{mL}\end{array}$ & $\begin{array}{l}0.3-5.8 \\
\mathrm{ng} / \mathrm{mL}\end{array}$ & $-\cdots$ & 2019 & [88] \\
\hline Goat milk & Clinafloxacin & FPIA & Centrifugation & $29.3 \mu \mathrm{g} / \mathrm{L}$ & $4.1 \mu \mathrm{g} / \mathrm{L}$ & $86.8-104.5$ & 2015 & [89] \\
\hline
\end{tabular}


Table 5. Cont.

\begin{tabular}{|c|c|c|c|c|c|c|c|c|}
\hline Analytes & Antibiotics & Detection & Extraction & $\mathrm{IC}_{50}$ & LOD & $\begin{array}{l}\text { Recovery } \\
(\%)\end{array}$ & Year & References \\
\hline \multirow{3}{*}{$\begin{array}{c}\text { Egg, } \\
\text { honey, and } \\
\text { pork }\end{array}$} & \multirow{3}{*}{ Sulfamethazine } & \multirow{3}{*}{$\begin{array}{l}\text { Immunochromatographic } \\
\text { assay }\end{array}$} & \multirow{3}{*}{ Centrifugation } & \multirow{3}{*}{$-\cdots$} & $\begin{array}{c}0.016 \\
\mathrm{ng} / \mathrm{mL}\end{array}$ & $90.5-113.9$ & \multirow{3}{*}{2020} & \multirow{3}{*}{ [85] } \\
\hline & & & & & $\begin{array}{c}0.049 \\
\mathrm{ng} / \mathrm{mL}\end{array}$ & $82.4-112.0$ & & \\
\hline & & & & & $\begin{array}{c}0.029 \\
\mathrm{ng} / \mathrm{mL}\end{array}$ & 79.8-93.4 & & \\
\hline $\begin{array}{l}\text { Chicken } \\
\text { muscle }\end{array}$ & Fluoroquinolones & $\begin{array}{c}\text { ic-ELISA } \\
\text { Lateral Flow Test Strip }\end{array}$ & Centrifugation & $0.2 \mathrm{ng} / \mathrm{mL}$ & $\begin{array}{c}0.082 \\
\mathrm{ng} / \mathrm{mL}\end{array}$ & $\ldots$ & 2017 & [90] \\
\hline
\end{tabular}

Note: ic-ELISA = Indirect complete enzyme-linked immunosorbent assay, FPIA = Fluorescence polarization immunoassay, PEG Precipitation $=$ Polyethylene Glycol Precipitation.

\subsection{Surface-Enhanced Raman Spectroscopy (SERS)-Based Methods}

SERS is a new technique developed based on Raman spectroscopy; this technique has benefits of high detection speed, low detection cost, and simple operation, and the high statistical binding of target analytes to active sites or "hot spots" of noble metal nanostructures is crucial for enhanced detection sensitivity [92]. The core components of a SERS-based method are a target molecule, a metal nanostructure, and electromagnetic radiation [93]. Previously, metal or metal oxide film layers were deposited on the surface to enhance the Raman signal to detect antibiotics. Recently, the majority of SERS-based sensor substrates were modified with metal nanoparticles [94], primarily gold or silver colloids. For instance, ciprofloxacin was physically adsorbed on a self-assembling gold nanofilm for quantitative detection, and SERS was utilized to detect it in fish [95]. A schematic of the pretreatment of fish samples followed by SERS detection on the gold nanofilm is shown in Figure 10. Jiang et al. assembled silver nanoparticles on a glass substrate to prepare SERS substrate to detect benzylpenicillin sodium [96].
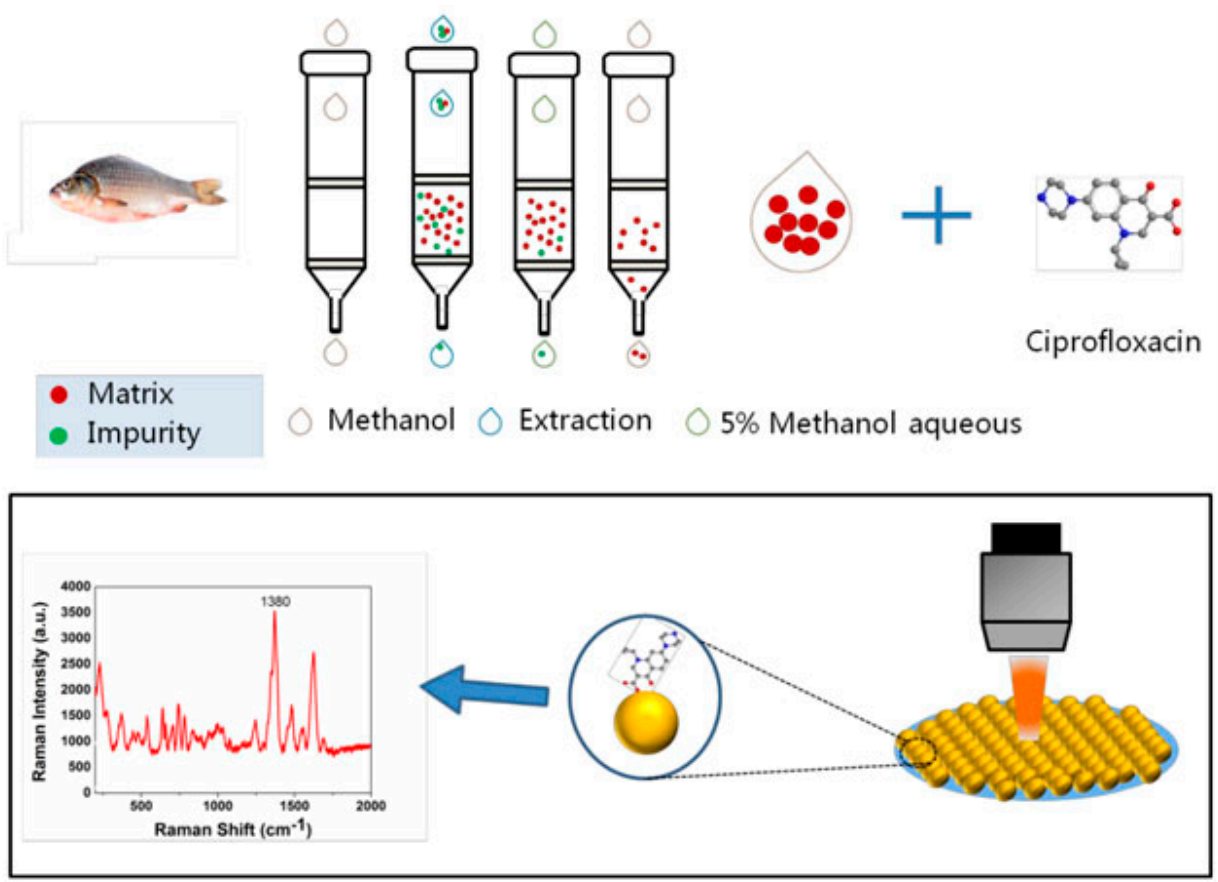

Figure 10. Schematic of the pretreatment of fish samples with SERS detection of ciprofloxacin on a self-assembled gold nanofilm (Reproduced with permission of the publisher) [95].

Recently, a unique methodology based on SERS combined with gold nanoparticles was devised for rapid detection of amoxicillin residues in duck flesh [97]. Similarly, another 
method was devised that uses gold nanoparticles/porous silicon (AuNPs/PSi) as a SERS active substrate for rapid and precise detection of ultra-low concentrations of penicillin G [98]; porous silicon surface modification enhances the density of hot spots and specific surface area of nanoparticles, resulting in improved performance and reproducibility [99]. Likewise, Ali et al. used Psi/AuNPs SERS sensors with a mud-like structure to detect ultra-low concentrations of amoxicillin, and enhanced SERS activity were obtained due to a higher density of small sizes of hot spot regions [100]. SERS substrates made of nanoparticles are extensively utilized for signal enhancement; however, inconsistencies of SERS signals were observed in some cases due to random distribution of nanoparticles, difficulties in controlling interparticle gap, and difficulties in fabrication of metal nanoparticles with high uniformity $[101,102]$.

In recent years, a combination method between SERS and lateral flow assay (LFA) has been used. Shi et al. used gold nanoparticles (AuNPs) conjugated to the Raman active molecule 4-amino thiophenol (PATP) and to monoclonal antibodies against neomycin and norfloxacin to develop multiple immuno-nanoprobes based on SERS for ultrasensitive detection of neomycin and quinolones via LFA, and these exhibited high detection sensitivity and satisfactory recovery from spiked milk samples [103]. In addition, Fan et al. employed a SERS-based lateral flow immunosensor method for simultaneous determination of tetracycline and penicillin residues in milk with the use of synthesized Au@Ag nanoparticles labeled with Raman molecules as a SERS substrate [104]. Besides this, with the emergence of novel materials such as carbon nanotubes and graphene oxide (GO), the adsorption capacity and sensitivity of SERS sensors can be boosted by incorporating these materials into sensing devices [93]. For the enrichment and SERS detection of antibiotics from water samples, silver nanoparticles (AgNPs) and carbon nanotube-intercalated graphene oxide laminar membranes (Ag NPs/CNT-GO membranes) were successfully fabricated [105]. The produced AgNPs/CNT-GO membranes displayed a high enrichment ability due to the $\pi$ - $\pi$-stacking and electrostatic interactions of GO with antibiotic molecules, which increased the sensitivity of SERS measurements allowing the detection of antibiotics at sub-nM concentration levels [105].

Likewise, a method of integrating SPME and SERS by co-deposition of reduced graphene oxide (RGO) and silver on silver-copper $(\mathrm{Ag}-\mathrm{Cu})$ alloy fibers was developed for detection of sulfadiazine and sulfamethoxazole in spiked tissue mimics, and such a hybrid coating exhibits a high SERS enhancement factor [106]. On the other hand, newly developed semiconductor SERS-active substrates $\left(\mathrm{TiO}_{2}, \mathrm{CuTe}\right.$, etc.) attracted increased interest [107], and such semiconductor SERS substrates have an ultra-sensitive detection potential under low concentrations and remarkable stability with a high SERS effect due to charge transfer (CT) phenomena as compared to the electromagnetic enhancement of metal SERS substrates [108]. For instance, Wang et al. developed a SERS strategy based on a semiconducting $\mathrm{Ag}-\mathrm{TiO}_{2}$ substrate for ultrasensitive detection of five quinolones (difloxacin hydrochloride, ciprofloxacin, enoxacin, enrofloxacin, and danofloxacin) in water samples [109]. Moreover, $\mathrm{Ag}-\mathrm{TiO}_{2}$ nanoparticles can also act as an efficient photocatalyst for antibiotic residues degradation, thereby showing excellent potential for simultaneous detection and degradation of antibiotic residues in the real environment [109].

For further improving sensing performance, a transparent SERS substrate was developed. Muhammad et al. fabricated and optimized a transparent SERS substrate composed of highly ordered AgNP arrays through anodic aluminum oxide (AAO) template-assisted electrochemical deposition approach for highly sensitive detection of tetracycline and dicyandiamide residues in milk samples [101]. A schematic of the experimental procedure of using transparent SERS substrate for the determination of antibiotics in milk samples is shown in Figure 11. 


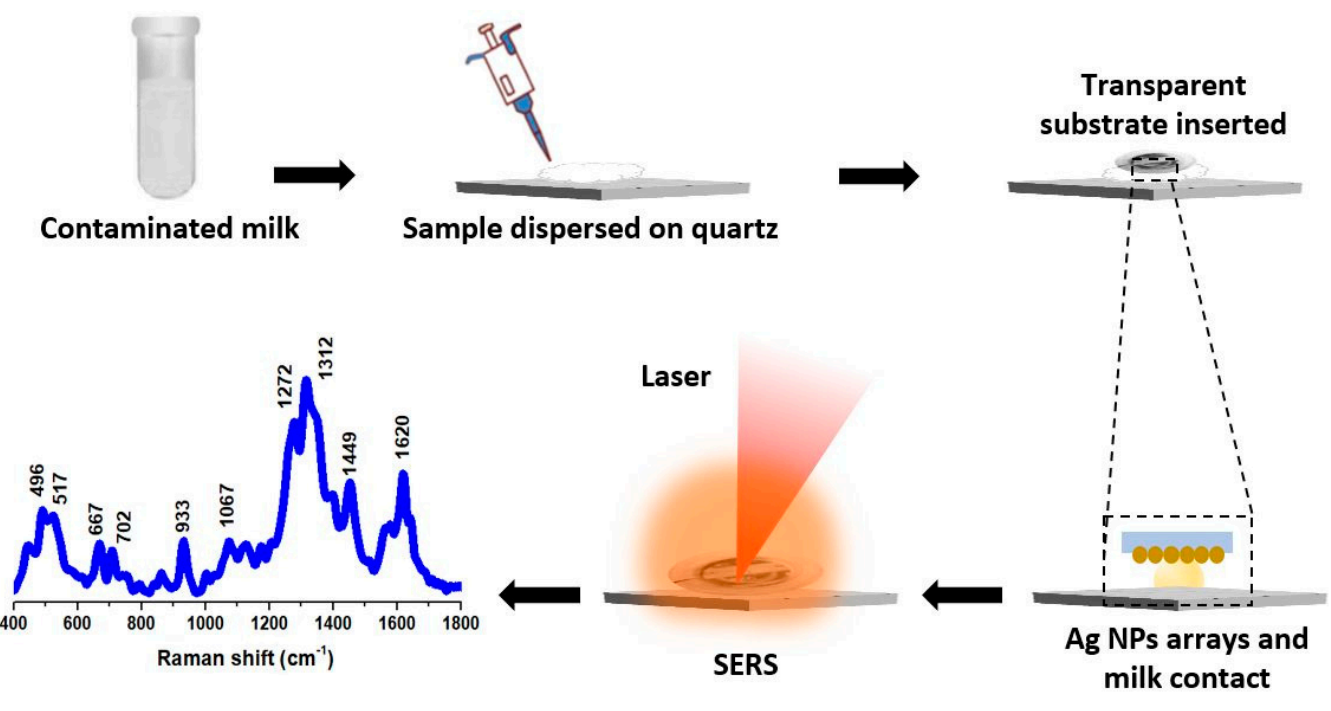

Figure 11. Schematic of the experimental procedure of using transparent SERS substrate for the determination of antibiotics in milk samples. (Reproduced with permission of the publisher) [101].

Xie et al. used a combination of molecularly imprinted polymers with Au as a SERS substrate to detect chloramphenicol in milk samples [110]. Likewise, Ashley et al. employed magnetic molecularly imprinted polymer (MMIP) microspheres for selective extraction, and vertical gold $(\mathrm{Au})$ capped silicon nanopillars as a SERS active substrate to detect cloxacillin in pig plasma [111]. Additionally, hybrid nanomaterials were prepared using magnetite nanoparticles (MNPs) and by decorating them with gold nanostars (AuNSs), and these hybrid nanostructures were found to serve as colloidal nano sorbent for SERSbased detection of tetracyclines in water samples [112]. A schematic of the procedure for the magnetic separation and SERS detection of antibiotics by using MNP-AuNS is illustrated in Figure 12. Thus, the key of SERS-based detection of antibiotics is primarily focused on enhancing SERS signals, repeatability, and stability of SERS measurements [94]. Different SERS-based methods, along with their analytical performance for the detection of antibiotics in different food samples, are summarized in Table 6.
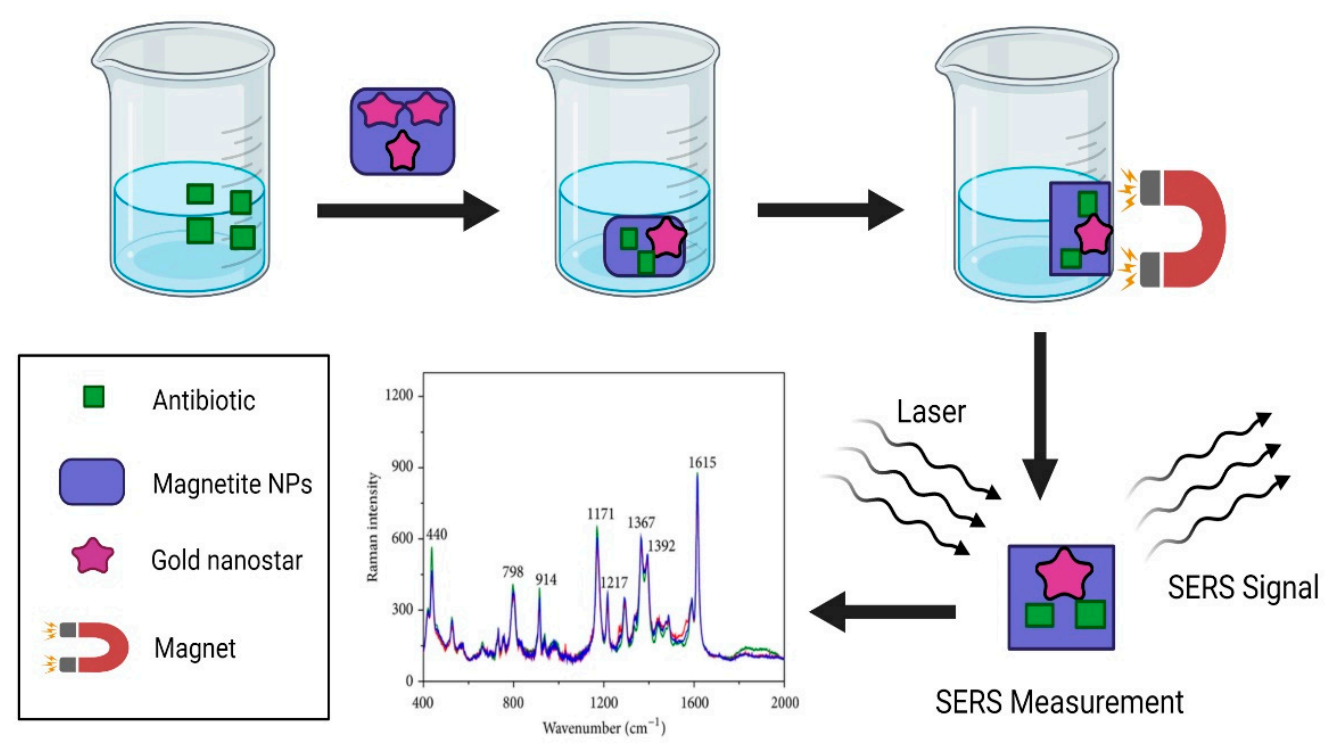

Figure 12. Schematic representation of SERS-based detection of antibiotics using Magnetite NPS-AuNSs. 
Table 6. The surface-enhanced Raman spectra (SERS)-based methods for antibiotics detection.

\begin{tabular}{|c|c|c|c|c|c|c|c|}
\hline Analytes & $\begin{array}{c}\text { SERs } \\
\text { Activenanomaterial }\end{array}$ & $\begin{array}{c}\text { Target } \\
\text { Antibiotics }\end{array}$ & Extraction & LOD & $\begin{array}{l}\text { Recoveries } \\
(\%)\end{array}$ & Year & References \\
\hline Milk & Ag-AgNPs & Penicillin G & $\begin{array}{l}\text { Centrifugation } \\
\text { and } \\
\text { Acetonitrile } \\
\text { extraction }\end{array}$ & $0.85 \mu \mathrm{g} / \mathrm{kg}$ & $76-97$ & 2017 & [113] \\
\hline Fish & Gold nanofilm & Ciprofloxacin & $\begin{array}{l}\text { Centrifugation } \\
\text { and SPE }\end{array}$ & $0.19 \mu \mathrm{g} / \mathrm{mL}$ & $84.6-103.8$ & 2019 & [95] \\
\hline Duck & AuNPs & Amoxicillin & Centrifugation & $0.2 \mathrm{mg} / \mathrm{L}$ & $96-139$ & 2017 & [97] \\
\hline Milk & Au@AgNPs & $\begin{array}{l}\text { Tetracyclines } \\
\text { Penicillins }\end{array}$ & - - & $\begin{array}{l}0.015 \mathrm{ng} / \mathrm{mL} \\
0.010 \mathrm{ng} / \mathrm{mL}\end{array}$ & $88.8-111.3$ & 2020 & [104] \\
\hline Water & $\mathrm{Ag}-\mathrm{TiO}_{2}$ & Danofloxacin & Centrifugation & $\begin{array}{c}3.16 \times 10^{-11} \\
\mathrm{~mol} / \mathrm{L}\end{array}$ & $>80.8$ & 2019 & [109] \\
\hline $\begin{array}{c}\text { Animal } \\
\text { tissue mimics }\end{array}$ & $\mathrm{RGO} / \mathrm{Ag}$ & $\begin{array}{c}\text { Sulfonamide } \\
\text { Sulfamethoxazole }\end{array}$ & - & $\begin{array}{l}1.9 \mathrm{ng} / \mathrm{mL} \\
4.4 \mathrm{ng} / \mathrm{mL}\end{array}$ & $-\ldots$ & 2018 & [106] \\
\hline $\begin{array}{l}\text { Chicken and } \\
\text { water }\end{array}$ & $\mathrm{Au}-\mathrm{Ag}$ composites & Ciprofloxacin & Centrifugation & $\begin{array}{l}2 \times 10^{-7} \mathrm{M} \\
8 \times 10^{-8} \mathrm{M}\end{array}$ & 91-105 & 2017 & [114] \\
\hline
\end{tabular}

Note: $\mathrm{Ag}-\mathrm{AgNPs}=$ Silver-Silver nanoparticles, $\mathrm{SPE}=$ Solid-phase extraction, AuNPs $=$ Gold nanoparticles, $\mathrm{Ag}-\mathrm{TiO}_{2}=\mathrm{Silver}-\mathrm{Titanium}$ dioxide, $\mathrm{RGO} / \mathrm{Ag}=$ Reduced graphene oxide

\subsection{Biosensors}

A biosensor is a functional integrated device that combines a biological recognition element or bioreceptor for generating signals that vary as a function of the concentration of analytes present in a sample [115]. Biosensors emerged as an innovative alternative tool for rapid, sensitive, and on-site screening of antibiotic residues in food products [19]. Currently, fluorescent, electrochemical, colorimetric, surface plasmon resonance (SPR), and quartz crystal microbalance (QCM) biosensor techniques are most commonly used for the screening of antibiotic residues $[30,116]$. Fluorescent biosensors are powerful analytical tools for the detection of antibiotics present in different matrices due to their inherent advantages, such as high sensitivity, high selectivity, operation convenience, rapid hybridization kinetics, and ease of automation [117]. Fluorescent biosensors based on GO and AuNPs nanomaterial-based quenchers are used for antibiotics detection. Tan et al. designed a GO hydrogel-based fluorescence aptasensor with ssDNA as the recognition element for oxytetracycline detection, and the limit of quantitation (LOQ) of $25 \mu \mathrm{g} / \mathrm{L}$ was achieved [118]. In other studies, an aptamer-based fluorescent biosensor was developed to detect chloramphenicol using MNPs and UCNPs [29,119]. Similarly, Yue et al. reported sensitive fluorescent biosensors based on UCNPs for the detection of kanamycin [120]. The schematic representation of biosensor-based detection of antibiotics is shown in Figure 13.

Likewise, DNA and nanoparticle colorimetric biosensors have gained significant interest in antibiotic detection because of the inherent optical properties of nanomaterials, and the signal can be detected using smartphones and UV-Vis spectrophotometers [121,122]. Several colorimetric reagents, including metallic nanoparticles, visible dyes, enzymes, and metal ions, were employed to fabricate sensor arrays for the analysis of different types of antibiotics in various samples [123]. A chemiluminescent (CL)-based biosensor was developed for simultaneous detection of three antibiotics, including oxytetracycline, tetracyclines, and kanamycin in milk samples [124]. Emrani et al. developed a colorimetric aptasensor, based on aqueous gold nanoparticles and double-stranded DNA (dsDNA), for the detection of streptomycin in milk and serum samples [125]. In the absence of streptomycin, there is a salt-induced aggregation of gold nanoparticles resulting in blue color, while in the presence of streptomycin, the gold nanoparticles are dispersed, showing a wine-red color [125]. 


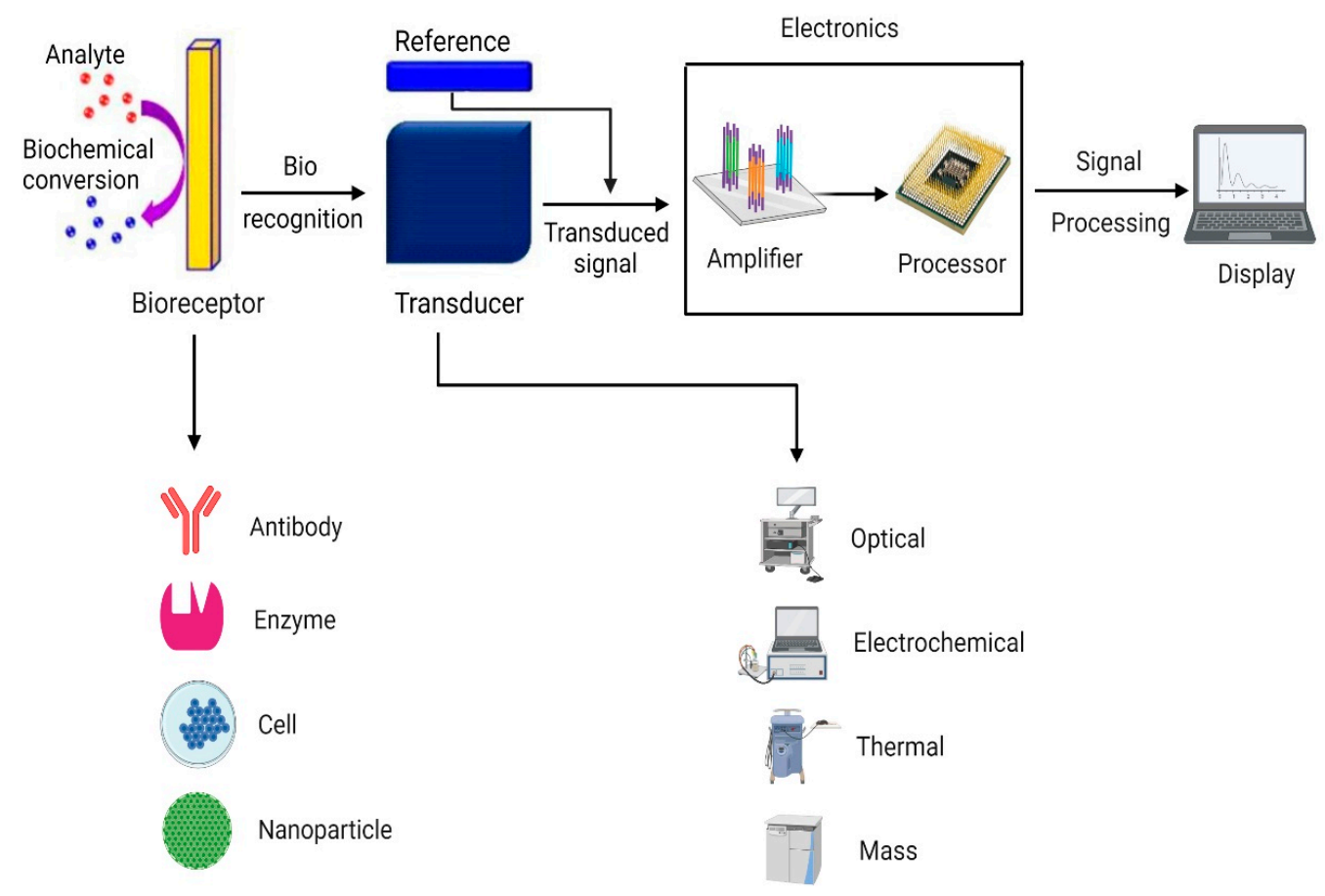

Figure 13. Biosensor-based detection of antibiotics.

Additionally, electrochemiluminescent biosensors (ECL) are very sensitive tools for the detection of antibiotics in different samples; ECL is based on the principle of production of light from an electrochemical reaction [126]. Yang et al. developed a chemiluminescence aptasensor for sensitive and selective detection of sulfamethazine in milk samples by employing a supernormal aptamer [127]. The aptamers were developed based on in vitro selection and were further analyzed by molecular docking [127]. The detection limit obtained was $0.92 \mathrm{ng} / \mathrm{mL}$ [127]. Similarly, surface plasmon resonance (SPR) biosensors belong to a powerful optical technology whose working principle is based on oscillation at the interface between two materials that can be generated by photons and electrons [128]. A label-free SPR aptasensor was developed by immobilizing a specific aptamer on a gold surface, and the aptasensor was used for real-time detection of ampicillin with a linear range of 2.5-1000 $\mu \mathrm{mol} \mathrm{L}-1$ and a limit of detection of $1 \mu \mathrm{mol} \mathrm{L}^{-1}$ [129].

High Fundamental Frequency Quartz Crystal Microbalance (HFF-QCMD) has the potential for simultaneous detection of several samples in a single analysis by integrating several sensors, thereby saving time and minimizing sample consumption. Sulfathiazole in honey was detected using a piezoelectric immunosensor based on HFF-QCMD technology with a LOD that was 40-50 times lower than those reported by other techniques [130]. The HFF-QCMD immunosensor was envisioned to be a feasible alternative to current techniques for the highly sensitive and rapid determination of sulfathiazole in honey with minimum sample preparation [130]. Electrochemical biosensor (ECB) is one of the most remarkable devices, and the working principle of ECB is based on chemical reactions occurring between immobilized biomolecules and target analytes that convert chemical information into measurable electrical signals [131]. A highly sensitive and specific homogeneous electrochemical aptasensor for ampicillin detection was developed by Wang et al. using target-induced and T7 exonuclease-assisted dual recycling signal amplification strategy, and the detection limit obtained was $4.0 \mathrm{ppm}$ [132]. The principle of the assay and the differential pulse voltammetric (DPV) response as a function of ampicillin concentration are shown in Figure 14. A brief description and the analytical performance of various biosensors are outlined in Table 7. 


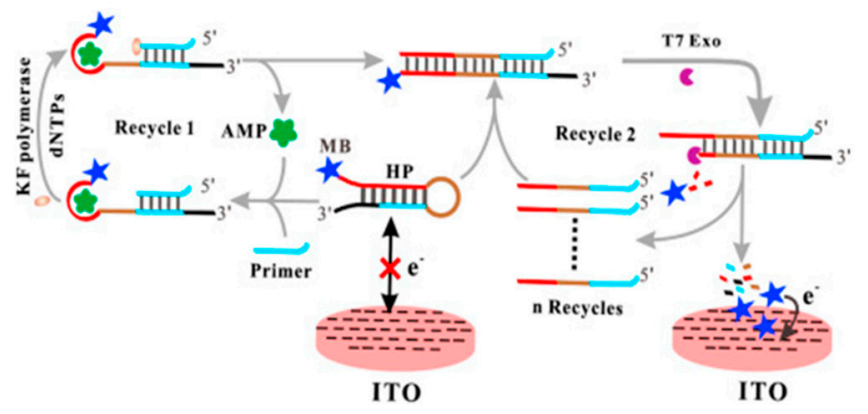

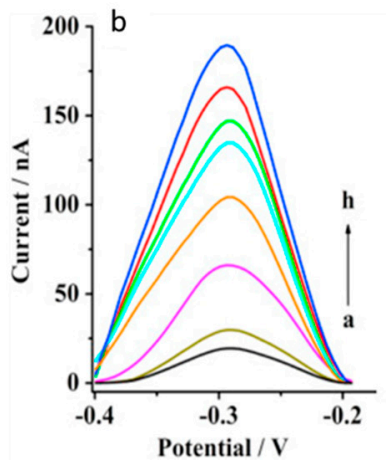

Figure 14. (a) Schematic showing the principle of homogeneous electrochemical strategy for highly sensitive detection of ampicillin and (b) differential pulse voltammetric response as a function of ampicillin concentration (reproduced with permission of the publisher) [132].

Table 7. Different types of biosensors for the detection of antibiotics.

\begin{tabular}{|c|c|c|c|c|c|c|c|}
\hline Biosensor & $\begin{array}{l}\text { Detection } \\
\text { Method }\end{array}$ & $\begin{array}{c}\text { Target } \\
\text { Antibiotics }\end{array}$ & Bioreceptor & Sample & LOD & Year & References \\
\hline \multirow{4}{*}{$\begin{array}{l}\text { Electrochemical } \\
\text { biosensor }\end{array}$} & Amperometry & Sulfapyridine & Antibody & Milk & $2.4 \mathrm{ng} / \mathrm{mL}$ & 2018 & [133] \\
\hline & $\begin{array}{l}\text { Electrochemical } \\
\text { impedance } \\
\text { spectroscopy } \\
\text { (EIS) }\end{array}$ & Tetracyclines & Antibody & Water & $12.4 \mathrm{ng} / \mathrm{mL}$ & 2020 & [134] \\
\hline & $\begin{array}{l}\text { Differential } \\
\text { pulse } \\
\text { voltammetry } \\
\text { (DPV) }\end{array}$ & Ampicillin & Aptamer & Milk & $\begin{array}{c}3.8 \times 10^{-4} \\
\mathrm{ng} / \mathrm{mL}\end{array}$ & 2015 & [135] \\
\hline & Amperometry & Chloramphenicol & Antibody & $\begin{array}{c}\text { Pork, } \\
\text { chicken, beef }\end{array}$ & $0.045 \mathrm{ng} / \mathrm{mL}$ & 2016 & [136] \\
\hline \multirow{3}{*}{$\begin{array}{l}\text { Optical } \\
\text { biosensor }\end{array}$} & Colorimetric & Tobramycin & Aptamer & $\begin{array}{c}\text { Milk, chicken, } \\
\text { egg }\end{array}$ & $10.89 \mathrm{ng} / \mathrm{mL}$ & 2018 & [122] \\
\hline & $\begin{array}{l}\text { Chemi- } \\
\text { luminescent } \\
(\mathrm{CL})\end{array}$ & Sulfamethazine & Aptamer & Milk & $0.92 \mathrm{ng} / \mathrm{mL}$ & 2019 & [127] \\
\hline & $\begin{array}{l}\text { Surface } \\
\text { plasmon } \\
\text { resonance } \\
\text { (SPR) }\end{array}$ & Enrofloxacin & Antibody & Milk & $0.07 \mathrm{ng} / \mathrm{mL}$ & 2017 & [137] \\
\hline \multirow{3}{*}{$\begin{array}{l}\text { Mass sensitive } \\
\text { biosensors }\end{array}$} & $\begin{array}{l}\text { Piezoelectric } \\
\text { quartz crystal } \\
\text { microbalance } \\
(\mathrm{QCM})\end{array}$ & Streptomycin & Antibody & Milk & $0.3 \mathrm{ng} / \mathrm{mL}$ & 2015 & [138] \\
\hline & $\begin{array}{l}\text { Piezoelectric } \\
\text { surface } \\
\text { acoustic wave } \\
\text { (SAW) }\end{array}$ & Penicillin G & Antibody & Milk & $2.2 \mathrm{ng} / \mathrm{mL}$ & 2016 & [139] \\
\hline & Cantilever & Oxytetracycline & Aptamer & Meat, egg & $0.85 \mathrm{ng} / \mathrm{mL}$ & 2015 & [140] \\
\hline
\end{tabular}

\section{Conclusions and Future Perspectives}

The use of antibiotics in animals can result in antibiotic residues in food products such as milk, meat, and eggs. These antibiotic residues can have adverse health effects, and to protect public health, MRLs of antibiotics in food products were established. A wide range of analytical methods was therefore developed for highly sensitive and selective detection 
and quantification of antibiotic residues in food samples. The LOD and LOQ values are found to depend on the antibiotics and the method employed for their detection, and these values are found to be lower than their MRLs. Mass spectrometry is a highly sensitive and selective technique, but the instrument is expensive, bulky, and consumes high power; thus, the recent research is more focused on developing an alternative. The optimization of the mass spectrometry has provided a better response for the quantification of antibiotic residues. To achieve good analytical results, sample pretreatment is an essential step where SPE is extensively used as a pretreatment approach in antibiotics detection. The development of highly selective SPE sorbents, such as magnetic sorbents, molecularly imprinted sorbents, etc., will enhance the performance of the chromatography and CEbased methods in the future towards detection of antibiotic residues. The selection of column and mobile phase is crucial while separating antibiotics using chromatography for the effective separation of specific antibiotics from a complex mixture. Similarly, in the case of $\mathrm{CE}$, buffer type, $\mathrm{pH}$, and voltage need to be adjusted properly such that targeted antibiotics could be separated from interfering species. Future development of online or automatic extraction and detection will make chromatography and CE more applicable in the places such as animal farms where antibiotics need to be detected quickly.

Recently, advancements were made in immunological assays, SERS, and biosensors for the detection of antibiotics. These techniques use monoclonal antibodies, nanoparticles, DNA, etc., and are found to be comparatively sensitive, selective, and accurate. Immunological methods can also be used as on-the-spot tools for the detection of antibiotics. In the future, research should be directed towards the production of directionally mutated proteins or antibodies that can specifically detect particular antibiotics. Further research should be focused on fabricating more uniform nanoparticles so that consistent SERS signals can be observed during analysis. Moreover, another avenue for research could be the development of more effective biosensors, which are promising tools for the detection and quantification of antibiotics in food products. The analytical performance of these biosensors can be enhanced by improving electrode materials, transducers, and biorecognition elements.

Author Contributions: Conceptualization, N.P. and B.P.R.; methodology, R.P.Y.; software, A.P.T. and B.A.; writing—original draft preparation, S.D., R.T., B.M., A.P.T., B.A., S.B., R.P.Y., S.G., P.S. and B.B.T.; writing-review and editing, B.P.R., N.P., B.M., S.D. and N.A.; editing images, S.A.; visualization, B.P.R.; supervision and project administration, N.P. All authors have read and agreed to the published version of the manuscript.

Funding: This study was financially supported under Collaborative Research Grants (Award No.: CRG-75/76-S\&T-1) by the University Grants Commission, Nepal.

Institutional Review Board Statement: Not applicable.

Informed Consent Statement: Not applicable.

Data Availability Statement: Not applicable.

Acknowledgments: We are thankful to Binod Rayamajhee (UNSW, Sydney) for editing the microbiological contents of this manuscript.

Conflicts of Interest: The authors declare no conflict of interest.

\section{References}

1. Chandler, C.I.R. Current Accounts of Antimicrobial Resistance: Stabilisation, Individualisation and Antibiotics as Infrastructure. Palgrave Commun. 2019, 5, 53. [CrossRef]

2. Angelakis, E.; Merhej, V.; Raoult, D. Related Actions of Probiotics and Antibiotics on Gut Microbiota and Weight Modification. Lancet Infect. Dis. 2013, 13, 889-899. [CrossRef]

3. Menkem, Z.E.; Ngangom, B.L.; Tamunjoh, S.S.A.; Boyom, F.F. Antibiotic Residues in Food Animals: Public Health Concern. Acta Ecol. Sin. 2019, 39, 411-415. [CrossRef]

4. Gothwal, R.; Shashidhar, T. Antibiotic Pollution in the Environment: A Review: Antibiotic Pollution in the Environment. Clean Soil Air Water 2015, 43, 479-489. [CrossRef] 
5. Ji, K.; Kho, Y.; Park, C.; Paek, D.; Ryu, P.; Paek, D.; Kim, M.; Kim, P.; Choi, K. Influence of Water and Food Consumption on Inadvertent Antibiotics Intake among General Population. Environ. Res. 2010, 110, 641-649. [CrossRef]

6. Santos, L.; Ramos, F. Analytical Strategies for the Detection and Quantification of Antibiotic Residues in Aquaculturefishes: A Review. Trends Food Sci. Technol. 2016, 52. [CrossRef]

7. Joshi, A.; Kim, K.-H. Recent Advances in Nanomaterial-Based Electrochemical Detection of Antibiotics: Challenges and Future Perspectives. Biosens. Bioelectron. 2020, 153, 112046. [CrossRef]

8. Bueno, I.; Williams-Nguyen, J.; Hwang, H.; Sargeant, J.M.; Nault, A.J.; Singer, R.S. Systematic Review: Impact of Point Sources on Antibiotic-Resistant Bacteria in the Natural Environment. Zoonoses Public Health 2018, 65, e162-e184. [CrossRef]

9. Rozman, U.; Duh, D.; Cimerman, M.; Turk, S.Š. Hospital Wastewater Effluent: Hot Spot for Antibiotic Resistant Bacteria. J. Water Sanit. Hyg. Dev. 2020, 10, 171-178. [CrossRef]

10. Petrovich, M.L.; Zilberman, A.; Kaplan, A.; Eliraz, G.R.; Wang, Y.; Langenfeld, K.; Duhaime, M.; Wigginton, K.; Poretsky, R.; Avisar, D.; et al. Microbial and Viral Communities and Their Antibiotic Resistance Genes Throughout a Hospital Wastewater Treatment System. Front. Microbiol. 2020, 11, 153. [CrossRef] [PubMed]

11. Kumar, A.; Pal, D. Antibiotic Resistance and Wastewater: Correlation, Impact and Critical Human Health Challenges. J. Environ. Chem. Eng. 2018, 6, 52-58. [CrossRef]

12. Chen, J.; Ying, G.-G.; Deng, W.-J. Antibiotic Residues in Food: Extraction, Analysis, and Human Health Concerns. J. Agric. Food Chem. 2019, 67, 7569-7586. [CrossRef] [PubMed]

13. Phillips, I. Does the Use of Antibiotics in Food Animals Pose a Risk to Human Health? A Critical Review of Published Data. J. Antimicrob. Chemother. 2003, 53, 28-52. [CrossRef]

14. Kneebone, J.; Tsang, P.C.W.; Towson, D.H. Rapid Antibiotic Screening Tests Detect Antibiotic Residues in Powdered Milk Products. J. Dairy Sci. 2010, 93, 3961-3964. [CrossRef]

15. Jammoul, A.; El Darra, N. Evaluation of Antibiotics Residues in Chicken Meat Samples in Lebanon. Antibiotics 2019, 8, 69. [CrossRef] [PubMed]

16. Farouk, F; Azzazy, H.M.E.; Niessen, W.M.A. Challenges in the Determination of Aminoglycoside Antibiotics, a Review. Anal. Chim. Acta 2015, 890, 21-43. [CrossRef] [PubMed]

17. Larsson, D.G.J. Antibiotics in the Environment. Upsala J. Med. Sci. 2014, 119, 108-112. [CrossRef] [PubMed]

18. Majdinasab, M.; Mishra, R.K.; Tang, X.; Marty, J.L. Detection of Antibiotics in Food: New Achievements in the Development of Biosensors. TrAC Trends Anal. Chem. 2020, 127, 115883. [CrossRef]

19. Khan, M.Z.H. Recent Biosensors for Detection of Antibiotics in Animal Derived Food. Crit. Rev. Anal. Chem. 2020, 1-11. [CrossRef] [PubMed]

20. Colombo, R.; Papetti, A. Advances in the Analysis of Veterinary Drug Residues in Food Matrices by Capillary Electrophoresis Techniques. Molecules 2019, 24, 4617. [CrossRef]

21. Li, W.; Dai, X.; Pu, E.; Bian, H.; Chen, Z.; Zhang, X.; Guo, Z.; Li, P.; Li, H.; Yong, Y.; et al. HLB-MCX-Based Solid-Phase Extraction Combined with Liquid Chromatography-Tandem Mass Spectrometry for the Simultaneous Determination of Four Agricultural Antibiotics (Kasugamycin, Validamycin A, Ningnanmycin, and Polyoxin B) Residues in Plant-Origin Foods. J. Agric. Food Chem. 2020, 68, 14025-14037. [CrossRef] [PubMed]

22. Di, S.; Yu, J.; Chen, P.; Zhu, G.; Zhu, S. Net-like Mesoporous Carbon Nanocomposites for Magnetic Solid-Phase Extraction of Sulfonamides Prior to Their Quantitation by UPLC-HRMS. Microchim. Acta 2020, 187, 112. [CrossRef] [PubMed]

23. Alampanos, V.; Samanidou, V.; Papadoyannis, I. Trends in Sample Preparation for the HPLC Determination of Penicillins in Biofluids. J. Appl. Bioanal. 2019, 5, 9-17. [CrossRef]

24. Sun, Y.; Zhao, J.; Liang, L. Recent Development of Antibiotic Detection in Food and Environment: The Combination of Sensors and Nanomaterials. Microchim. Acta 2021, 188, 21. [CrossRef]

25. Zhi, S.; Zhou, J.; Liu, H.; Wu, H.; Zhang, Z.; Ding, Y.; Zhang, K. Simultaneous Extraction and Determination of 45 Veterinary Antibiotics in Swine Manure by Liquid Chromatography-Tandem Mass Spectrometry. J. Chromatogr. B 2020, 1154, 122286. [CrossRef]

26. Lorenzetti, A.S.; Lista, A.G.; Domini, C.E. Reverse Ultrasound-Assisted Emulsification-Microextraction of Macrolides from Chicken Fat Followed by Electrophoretic Determination. LWT 2019, 113, 108334. [CrossRef]

27. Zhao, J.; Liu, P.; Yuan, H.; Peng, Y.; Hong, Q.; Liu, M. Rapid Detection of Tetracycline Residues in Duck Meat Using Surface Enhanced Raman Spectroscopy. J. Spectrosc. 2016, 2016, 1-6. [CrossRef]

28. Baghani, A.; Mesdaghinia, A.; Rafieiyan, M.; Soltan Dallal, M.M.; Douraghi, M. Tetracycline and Ciprofloxacin Multiresidues in Beef and Chicken Meat Samples Using Indirect Competitive ELISA. J. Immunoass. Immunochem. 2019, 40, 328-342. [CrossRef]

29. Gaudin, V. Advances in Biosensor Development for the Screening of Antibiotic Residues in Food Products of Animal Origin-A Comprehensive Review. Biosens. Bioelectron. 2017, 90, 363-377. [CrossRef]

30. Mungroo, N.; Neethirajan, S. Biosensors for the Detection of Antibiotics in Poultry Industry-A Review. Biosensors 2014, 4, 472-493. [CrossRef] [PubMed]

31. Hutchings, M.I.; Truman, A.W.; Wilkinson, B. Antibiotics: Past, Present and Future. Curr. Opin. Microbiol. 2019, 51, 72-80. [CrossRef]

32. Coates, A.R.; Halls, G.; Hu, Y. Novel Classes of Antibiotics or More of the Same?: New Antibiotic Classes Are Urgently Needed. Br. J. Pharmacol. 2011, 163, 184-194. [CrossRef] 
33. Ha, J.; Song, G.; Ai, L.-F.; Li, J.-C. Determination of Six Polyether Antibiotic Residues in Foods of Animal Origin by Solid Phase Extraction Combined with Liquid Chromatography-Tandem Mass Spectrometry. J. Chromatogr. B 2016, 1017-1018, 187-194. [CrossRef]

34. Xu, G.; Zhang, B.; Wang, X.; Li, N.; Zhao, Y.; Liu, L.; Lin, J.-M.; Zhao, R.-S. Porous Covalent Organonitridic Frameworks for Solid-Phase Extraction of Sulfonamide Antibiotics. Mikrochim. Acta 2018, 186, 26. [CrossRef] [PubMed]

35. Pérez-Rodríguez, M.; Pellerano, R.G.; Pezza, L.; Pezza, H.R. An Overview of the Main Foodstuff Sample Preparation Technologies for Tetracycline Residue Determination. Talanta 2018, 182, 1-21. [CrossRef]

36. Wang, X.; Li, P. Rapid Screening of Mycotoxins in Liquid Milk and Milk Powder by Automated Size-Exclusion SPE-UPLC-MS/MS and Quantification of Matrix Effects over the Whole Chromatographic Run. Food Chem. 2015, 173, 897-904. [CrossRef]

37. Deng, F.; Yu, H.; Pan, X.; Hu, G.; Wang, Q.; Peng, R.; Tan, L.; Yang, Z. Ultra-High Performance Liquid Chromatography Tandem Mass Spectrometry for the Determination of Five Glycopeptide Antibiotics in Food and Biological Samples Using Solid-Phase Extraction. J. Chromatogr. A 2018, 1538, 54-59. [CrossRef] [PubMed]

38. Li, T.; Wang, C.; Xu, Z.; Chakraborty, A. A Coupled Method of On-Line Solid Phase Extraction with the UHPLC-MS/MS for Detection of Sulfonamides Antibiotics Residues in Aquaculture. Chemosphere 2020, 254, 126765. [CrossRef] [PubMed]

39. Du, F.; Sun, L.; Tan, W.; Wei, Z.; Nie, H.; Huang, Z.; Ruan, G.; Li, J. Magnetic Stir Cake Sorptive Extraction of Trace Tetracycline Antibiotics in Food Samples: Preparation of Metal-Organic Framework-Embedded PolyHIPE Monolithic Composites, Validation and Application. Anal. Bioanal. Chem. 2019, 411, 2239-2248. [CrossRef] [PubMed]

40. Weng, R.; Sun, L.; Jiang, L.; Li, N.; Ruan, G.; Li, J.; Du, F. Electrospun Graphene Oxide-Doped Nanofiber-Based Solid Phase Extraction Followed by High-Performance Liquid Chromatography for the Determination of Tetracycline Antibiotic Residues in Food Samples. Food Anal. Methods 2019, 12, 1594-1603. [CrossRef]

41. Wang, R.; Li, C.; Li, Q.; Zhang, S.; lv, F.; Yan, Z. Electrospinning Fabrication of Covalent Organic Framework Composite Nanofibers for Pipette Tip Solid Phase Extraction of Tetracycline Antibiotics in Grass Carp and Duck. J. Chromatogr. A 2020, 1622, 461098. [CrossRef]

42. Figueiredo, L.; Erny, G.L.; Santos, L.; Alves, A. Applications of Molecularly Imprinted Polymers to the Analysis and Removal of Personal Care Products: A Review. Talanta 2016, 146, 754-765. [CrossRef] [PubMed]

43. Yang, B.; Wang, L.; Luo, C.; Wang, X.; Sun, C. Simultaneous Determination of 11 Aminoglycoside Residues in Honey, Milk, and Pork by Liquid Chromatography with Tandem Mass Spectrometry and Molecularly Imprinted Polymer Solid Phase Extraction. J. AOAC Int. 2017, 100, 1869-1878. [CrossRef] [PubMed]

44. Liu, X.; Xie, S.; Ni, T.; Chen, D.; Wang, X.; Pan, Y.; Wang, Y.; Huang, L.; Cheng, G.; Qu, W.; et al. Magnetic Solid-Phase Extraction Based on Carbon Nanotubes for the Determination of Polyether Antibiotic and s-Triazine Drug Residues in Animal Food with LC-MS/MS. J. Sep. Sci. 2017, 40, 2416-2430. [CrossRef] [PubMed]

45. Nasir, A.N.M.; Yahaya, N.; Zain, N.N.M.; Lim, V.; Kamaruzaman, S.; Saad, B.; Nishiyama, N.; Yoshida, N.; Hirota, Y. ThiolFunctionalized Magnetic Carbon Nanotubes for Magnetic Micro-Solid Phase Extraction of Sulfonamide Antibiotics from Milks and Commercial Chicken Meat Products. Food Chem. 2019, 276, 458-466. [CrossRef]

46. Arroyo-Manzanares, N.; Gámiz-Gracia, L.; García-Campaña, A.M. Alternative Sample Treatments for the Determination of Sulfonamides in Milk by HPLC with Fluorescence Detection. Food Chem. 2014, 143, 459-464. [CrossRef]

47. Wu, L.; Song, Y.; Hu, M.; Xu, X.; Zhang, H.; Yu, A.; Ma, Q.; Wang, Z. Determination of Sulfonamides in Butter Samples by Ionic Liquid Magnetic Bar Liquid-Phase Microextraction High-Performance Liquid Chromatography. Anal. Bioanal. Chem. 2015, 407, 569-580. [CrossRef]

48. Zhao, Y.; Wu, R.; Yu, H.; Li, J.; Liu, L.; Wang, S.; Chen, X.; Chan, T.-W.D. Magnetic Solid-Phase Extraction of Sulfonamide Antibiotics in Water and Animal-Derived Food Samples Using Core-Shell Magnetite and Molybdenum Disulfide Nanocomposite Adsorbent. J. Chromatogr. A 2020, 1610, 460543. [CrossRef]

49. Xu, G.; Dong, X.; Hou, L.; Wang, X.; Liu, L.; Ma, H.; Zhao, R.-S. Room-Temperature Synthesis of Flower-Shaped Covalent Organic Frameworks for Solid-Phase Extraction of Quinolone Antibiotics. Anal. Chim. Acta 2020, 1126, 82-90. [CrossRef]

50. Golzari Aqda, T.; Behkami, S.; Raoofi, M.; Bagheri, H. Graphene Oxide-Starch-Based Micro-Solid Phase Extraction of Antibiotic Residues from Milk Samples. J. Chromatogr. A 2019, 1591, 7-14. [CrossRef]

51. Song, X.; Zhou, T.; Li, J.; Su, Y.; Xie, J.; He, L. Determination of Macrolide Antibiotics Residues in Pork Using Molecularly Imprinted Dispersive Solid-Phase Extraction Coupled with LC-MS/MS. J. Sep. Sci. 2018, 41, 1138-1148. [CrossRef] [PubMed]

52. Xu, J.-J.; An, M.; Yang, R.; Tan, Z.; Hao, J.; Cao, J.; Peng, L.-Q.; Cao, W. Determination of Tetracycline Antibiotic Residues in Honey and Milk by Miniaturized Solid Phase Extraction Using Chitosan-Modified Graphitized Multiwalled Carbon Nanotubes. J. Agric. Food Chem. 2016, 64, 2647-2654. [CrossRef] [PubMed]

53. Arabsorkhi, B.; Sereshti, H. Determination of Tetracycline and Cefotaxime Residues in Honey by Micro-Solid Phase Extraction Based on Electrospun Nanofibers Coupled with HPLC. Microchem. J. 2018, 140, 241-247. [CrossRef]

54. Xie, Y.; Hu, Q.; Zhao, M.; Cheng, Y.; Guo, Y.; Qian, H.; Yao, W. Simultaneous Determination of Erythromycin, Tetracycline, and Chloramphenicol Residue in Raw Milk by Molecularly Imprinted Polymer Mixed with Solid-Phase Extraction. Food Anal. Methods 2018, 11, 374-381. [CrossRef]

55. Islas, G.; Rodriguez, J.A.; Perez-Silva, I.; Miranda, J.M.; Ibarra, I.S. Solid-Phase Extraction and Large-Volume Sample StackingCapillary Electrophoresis for Determination of Tetracycline Residues in Milk. J. Anal. Methods Chem. 2018, 2018, e5394527. [CrossRef] 
56. Betina, V. Bioautography in Paper and Thin-Layer Chromatography and Its Scope in the Antibiotic Field. J. Chromatogr. A 1973, 78, 41-51. [CrossRef]

57. Armentano, A.; Summa, S.; Lo Magro, S.; Palermo, C.; Nardiello, D.; Centonze, D.; Muscarella, M. Rapid Method for the Quantification of 13 Sulphonamides in Milk by Conventional High-Performance Liquid Chromatography with Diode Array Ultraviolet Detection Using a Column Packed with Core-Shell Particles. J. Chromatogr. A 2018, 1531, 46-52. [CrossRef]

58. Hui, W.; Li, Q.; Ma, H.; Wu, M.; Feng, K.; Zhu, H.; Yang, P.; Li, J.; Chen, C.; Yan, K. Rapid Screening for 15 Sulfonamide Residues in Foods of Animal Origin by High-Performance Liquid Chromatography-UV Method. J. Chromatogr. Sci. 2018, 56, 636-643. [CrossRef]

59. Łukaszewicz, P.; Białk-Bielińska, A.; Dołżonek, J.; Kumirska, J.; Caban, M.; Stepnowski, P. A New Approach for the Extraction of Tetracyclines from Soil Matrices: Application of the Microwave-Extraction Technique. Anal. Bioanal. Chem. 2018, 410, 1697-1707. [CrossRef]

60. Wang, Z.; Song, X.; Zhou, T.; Bian, K.; Zhang, F.; He, L.; Liu, Q. Simultaneous Determination of Ten Macrolides Drugs in Feeds by High Performance Liquid Chromatography with Evaporation Light Scattering Detection. RSC Adv. 2015, 5, 1491-1499. [CrossRef]

61. Song, X.; Xie, J.; Zhang, M.; Zhang, Y.; Li, J.; Huang, Q.; He, L. Simultaneous Determination of Eight Cyclopolypeptide Antibiotics in Feed by High Performance Liquid Chromatography Coupled with Evaporation Light Scattering Detection. J. Chromatogr. B 2018, 1076, 103-109. [CrossRef]

62. Mishra, A.; Chhonker, Y.S.; Bisen, A.C.; Prasad, Y.D.; Tulsankar, S.L.; Chandasana, H.; Dey, T.; Verma, S.K.; Bala, V.; Kanojiya, S.; et al. Rapid and Simultaneous Analysis of Multiple Classes of Antimicrobial Drugs by Liquid ChromatographyTandem Mass Spectrometry and Its Application to Routine Biomedical, Food, and Soil Analyses. ACS Omega 2020, 5, 31584-31597. [CrossRef]

63. Liu, Q.; Li, J.; Song, X.; Zhang, M.; Li, E.; Gao, F.; He, L. Simultaneous Determination of Aminoglycoside Antibiotics in Feeds Using High Performance Liquid Chromatography with Evaporative Light Scattering Detection. RSC Adv. 2017, 7, 1251-1259. [CrossRef]

64. Liu, T.; Zhang, C.; Zhang, F.; Nie, B.; Yuan, F.; Huang, H.; Li, H. Sensitive Determination of Four Polypeptide Antibiotic Residues in Milk Powder by High Performance Liquid Chromatography-Electrospray Tandem Mass Spectrometry. Chromatographia 2019, 82, 1479-1487. [CrossRef]

65. Wang, C.; Li, X.; Yu, F.; Wang, Y.; Ye, D.; Hu, X.; Zhou, L.; Du, J.; Xia, X. Multi-Class Analysis of Veterinary Drugs in Eggs Using Dispersive-Solid Phase Extraction and Ultra-High Performance Liquid Chromatography-Tandem Mass Spectrometry. Food Chem. 2021, 334, 127598. [CrossRef] [PubMed]

66. Lai, X.; Liu, J.; Xu, X.; Li, J.; Zhang, B.; Wei, L.; Cai, H.; Cheng, X. Ultrasensitive High-performance Liquid Chromatography Determination of Tetracycline Antibiotics and Their 4-epimer Derivatives Based on Dual Effect of Methanesulfonic Acid. J. Sep. Sci. 2020, 43, 398-405. [CrossRef]

67. Lu, Z.; Deng, F.; He, R.; Tan, L.; Luo, X.; Pan, X.; Yang, Z. A Pass-through Solid-Phase Extraction Clean-up Method for the Determination of 11 Quinolone Antibiotics in Chicken Meat and Egg Samples Using Ultra-Performance Liquid Chromatography Tandem Mass Spectrometry. Microchem. J. 2019, 151, 104213. [CrossRef]

68. Wang, K.; Lin, K.; Huang, X.; Chen, M. A Simple and Fast Extraction Method for the Determination of Multiclass Antibiotics in Eggs Using LC-MS/MS. J. Agric. Food Chem. 2017, 65, 5064-5073. [CrossRef] [PubMed]

69. Yu, H.; Jia, Y.; Wu, R.; Chen, X.; Chan, T.-W.D. Determination of Fluoroquinolones in Food Samples by Magnetic Solid-Phase Extraction Based on a Magnetic Molecular Sieve Nanocomposite Prior to High-Performance Liquid Chromatography and Tandem Mass Spectrometry. Anal. Bioanal. Chem. 2019, 411, 2817-2826. [CrossRef] [PubMed]

70. He, T.; Xu, Z.; Ren, J. Pressure-Assisted Electrokinetic Injection Stacking for Seven Typical Antibiotics in Waters to Achieve Mg/L Level Analysis by Capillary Electrophoresis with UV Detection. Microchem. J. 2019, 146, 1295-1300. [CrossRef]

71. Moreno-González, D.; Krulišová, M.; Gámiz-Gracia, L.; García-Campaña, A.M. Determination of Tetracyclines in Human Urine Samples by Capillary Electrophoresis in Combination with Field Amplified Sample Injection. Electrophoresis 2018, 39, 608-615. [CrossRef] [PubMed]

72. Ferreira, T.A.; Flores-Aguilar, J.F.; Santos, E.M.; Rodriguez, J.A.; Ibarra, I.S. New Poly(Ionic Liquid) Based Fiber for Determination of Oxytetracycline in Milk Samples by Application of SPME-CE Technique. Molecules 2019, 24, 430. [CrossRef] [PubMed]

73. Moreno-González, D.; Hamed, A.M.; Gilbert-López, B.; Gámiz-Gracia, L.; García-Campaña, A.M. Evaluation of a Multiresidue Capillary Electrophoresis-Quadrupole-Time-of-Flight Mass Spectrometry Method for the Determination of Antibiotics in Milk Samples. J. Chromatogr. A 2017, 1510, 100-107. [CrossRef] [PubMed]

74. Díaz-Quiroz, C.A.; Francisco Hernández-Chávez, J.; Ulloa-Mercado, G.; Gortáres-Moroyoqui, P.; Martínez-Macías, R.; Meza-Escalante, E.; Serrano-Palacios, D. Simultaneous Quantification of Antibiotics in Wastewater from Pig Farms by Capillary Electrophoresis. J. Chromatogr. B 2018, 1092, 386-393. [CrossRef] [PubMed]

75. An, J.; Wang, X.; Ming, M.; Li, J.; Ye, N. Determination of Sulfonamides in Milk by Capillary Electrophoresis with PEG@MoS2 as a Dispersive Solid-Phase Extraction Sorbent. R. Soc. Open Sci. 2018, 5, 172104. [CrossRef]

76. Dai, T.; Duan, J.; Li, X.; Xu, X.; Shi, H.; Kang, W. Determination of Sulfonamide Residues in Food by Capillary Zone Electrophoresis with On-Line Chemiluminescence Detection Based on an Ag(III) Complex. Int. J. Mol. Sci. 2017, 18, 1286. [CrossRef]

77. Hong, Y.; Guo, X.; Chen, G.; Zhou, J.; Zou, X.; Liao, X.; Hou, T. Determination of Five Macrolide Antibiotic Residues in Milk by Micellar Electrokinetic Capillary Chromatography with Field Amplified Sample Stacking. J. Food Saf. 2018, 38. [CrossRef] 
78. Lahouidak, S.; Soriano, M.L.; Salghi, R.; Zougagh, M.; Ríos, Á. Graphene Quantum Dots for Enhancement of Fluorimetric Detection Coupled to Capillary Electrophoresis for Detection of Ofloxacin. Electrophoresis 2019, 40, 2336-2341. [CrossRef]

79. Tejada-Casado, C.; Moreno-González, D.; Lara, F.J.; García-Campaña, A.M.; del Olmo-Iruela, M. Determination of Benzimidazoles in Meat Samples by Capillary Zone Electrophoresis Tandem Mass Spectrometry Following Dispersive Liquid-Liquid Microextraction. J. Chromatogr. A 2017, 1490, 212-219. [CrossRef] [PubMed]

80. Bosma, R.; Devasagayam, J.; Singh, A.; Collier, C.M. Microchip Capillary Electrophoresis Dairy Device Using Fluorescence Spectroscopy for Detection of Ciprofloxacin in Milk Samples. Sci. Rep. 2020, 10, 1-8. [CrossRef]

81. Tian, Z.; Gao, J.; Qin, W. Determination of Fluoroquinolones in Milk by Ionic Liquid-Mediated Two Phase Extraction Followed by Capillary Electrophoresis Analysis. Madr. J. Anal. Sci. Instrum. 2018, 3, 62-67. [CrossRef]

82. Kergaravat, S.V.; Nagel, O.G.; Althaus, R.L.; Hernández, S.R. Magneto Immunofluorescence Assay for Quinolone Detection in Bovine Milk. Food Anal. Methods 2020, 13, 1539-1547. [CrossRef]

83. Li, C.; Zhang, Y.; Eremin, S.A.; Yakup, O.; Yao, G.; Zhang, X. Detection of Kanamycin and Gentamicin Residues in Animal-Derived Food Using IgY Antibody Based Ic-ELISA and FPIA. Food Chem. 2017, 227, 48-54. [CrossRef] [PubMed]

84. Li, H.; Ma, S.; Zhang, X.; Li, C.; Dong, B.; Mujtaba, M.G.; Wei, Y.; Liang, X.; Yu, X.; Wen, K.; et al. Generic Hapten Synthesis, Broad-Specificity Monoclonal Antibodies Preparation, and Ultrasensitive ELISA for Five Antibacterial Synergists in Chicken and Milk. J. Agric. Food Chem. 2018, 66, 11170-11179. [CrossRef] [PubMed]

85. Wang, Z.; Hu, S.; Bao, H.; Xing, K.; Liu, J.; Xia, J.; Lai, W.H.; Peng, J. Immunochromatographic Assay Based on Time-Resolved Fluorescent Nanobeads for the Rapid Detection of Sulfamethazine in Egg, Honey, and Pork. J. Sci. Food Agric. 2020. [CrossRef]

86. Liang, X.; Sheng, Y.; Yu, W.; Zhao, S.; Shan, H.; Zhang, Q.; Wang, Z. Comparison of Chicken IgY and Mammalian IgG in Three Immunoassays for Detection of Sulfamethazine in Milk. Food Anal. Methods 2018, 11, 3452-3463. [CrossRef]

87. Shen, X.; Chen, J.; Lv, S.; Sun, X.; Dzantiev, B.B.; Eremin, S.A.; Zherdev, A.V.; Xu, J.; Sun, Y.; Lei, H. Fluorescence Polarization Immunoassay for Determination of Enrofloxacin in Pork Liver and Chicken. Molecules 2019, 24, 4462. [CrossRef]

88. Wang, G.; Xia, W.Q.; Liu, J.X.; Wang, J.P.; Liu, J. Directional Evolution of TetR Protein and Development of a Fluoroimmunoassay for Screening of Tetracyclines in Egg. Microchem. J. 2019, 150, 104184. [CrossRef]

89. Chen, J.; Shanin, I.A.; Lv, S.; Wang, Q.; Mao, C.; Xu, Z.; Sun, Y.; Wu, Q.; Eremin, S.A.; Lei, H. Heterologous Strategy Enhancing the Sensitivity of the Fluorescence Polarization Immunoassay of Clinafloxacin in Goat Milk. J. Sci. Food Agric. 2016, 96, 1341-1346. [CrossRef] [PubMed]

90. Mukunzi, D.; Suryoprabowo, S.; Song, S.; Liu, L.; Kuang, H. Development of an Indirect Enzyme-Linked Immunosorbent Assay and Lateral-Flow Test Strips for Pefloxacin and Its Analogues in Chicken Muscle Samples. Food Agric. Immunol. 2018, 29, 484-497. [CrossRef]

91. He, J.; Hu, J.; Thirumalai, D.; Schade, R.; Du, E.; Zhang, X. Development of Indirect Competitive ELISA Using Egg Yolk-Derived Immunoglobulin (IgY) for the Detection of Gentamicin Residues. J. Environ. Sci. Health Part B 2016, 51, 8-13. [CrossRef]

92. Liu, H.; Sun, Y.; Jin, Z.; Yang, L.; Liu, J. Capillarity-Constructed Reversible Hot Spots for Molecular Trapping inside Silver Nanorod Arrays Light up Ultrahigh SERS Enhancement. Chem. Sci. 2013, 4, 3490-3496. [CrossRef]

93. Jiang, Y.; Sun, D.-W.; Pu, H.; Wei, Q. Surface Enhanced Raman Spectroscopy (SERS): A Novel Reliable Technique for Rapid Detection of Common Harmful Chemical Residues. Trends Food Sci. Technol. 2018, 75, 10-22. [CrossRef]

94. Wang, Q.; Zhao, W.-M. Optical Methods of Antibiotic Residues Detections: A Comprehensive Review. Sens. Actuators B Chem. 2018, 269, 238-256. [CrossRef]

95. Zhang, Y.; Teng, Y.; Qin, Y.; Ren, Z.; Wang, Z. Determination of Ciprofloxacin in Fish by Surface-Enhanced Raman Scattering Using a Liquid-Liquid Self-Assembled Gold Nanofilm. Anal. Lett. 2020, 53, 660-670. [CrossRef]

96. Jiang, X.; Qin, X.; Yin, D.; Gong, M.; Yang, L.; Zhao, B.; Ruan, W. Rapid Monitoring of Benzylpenicillin Sodium Using Raman and Surface Enhanced Raman Spectroscopy. Spectrochim. Acta Part A Mol. Biomol. Spectrosc. 2015, 140, 474-478. [CrossRef]

97. Peng, Y.; Liu, M.; Chen, X.; Yuan, H.; Zhao, J. Surface-Enhanced Raman Spectroscopy Coupled with Gold Nanoparticles for Rapid Detection of Amoxicillin Residues in Duck Meat. Spectrosc. Lett. 2017, 50, 579-584. [CrossRef]

98. Wali, L.A.; Hasan, K.K.; Alwan, A.M. Rapid and Highly Efficient Detection of Ultra-Low Concentration of Penicillin G by Gold Nanoparticles/Porous Silicon SERS Active Substrate. Spectrochim. Acta A. Mol. Biomol. Spectrosc. 2019, 206, 31-36. [CrossRef]

99. Jabbar, A.A.; Alwan, A.M.; Haider, A.J. Modifying and Fine Controlling of Silver Nanoparticle Nucleation Sites and SERS Performance by Double Silicon Etching Process. Plasmonics 2018, 13, 1171-1182. [CrossRef]

100. Ali, W.H.; Dheyab, A.B.; Alwan, A.M.; Abber, Z.S. Study the Role of Mud-like Psi Morphologies on the Performance of AuNPS SERS Sensor for Efficient Detection of Amoxicillin. In AIP Conference Proceedings; AIP Publishing LLC: Melville, NY, USA, 2020; Volume 2290, p. 050061. [CrossRef]

101. Muhammad, M.; Yan, B.; Yao, G.; Chao, K.; Zhu, C.; Huang, Q. Surface-Enhanced Raman Spectroscopy for Trace Detection of Tetracycline and Dicyandiamide in Milk Using Transparent Substrate of Ag Nanoparticle Arrays. ACS Appl. Nano Mater. 2020, 3 , 7066-7075. [CrossRef]

102. Wang, X.; Shi, W.; She, G.; Mu, L. Surface-Enhanced Raman Scattering (SERS) on Transition Metal and Semiconductor Nanostructures. Phys. Chem. Chem. Phys. 2012, 14, 5891. [CrossRef] [PubMed]

103. Shi, Q.; Huang, J.; Sun, Y.; Deng, R.; Teng, M.; Li, Q.; Yang, Y.; Hu, X.; Zhang, Z.; Zhang, G. A SERS-Based Multiple ImmunoNanoprobe for Ultrasensitive Detection of Neomycin and Quinolone Antibiotics via a Lateral Flow Assay. Microchim. Acta 2018, 185, 84. [CrossRef] [PubMed] 
104. Fan, R.; Tang, S.; Luo, S.; Liu, H.; Zhang, W.; Yang, C.; He, L.; Chen, Y. Duplex Surface Enhanced Raman Scattering-Based Lateral Flow Immunosensor for the Low-Level Detection of Antibiotic Residues in Milk. Molecules 2020, 25, 5249. [CrossRef]

105. Qu, L.; Liu, Y.-Y.; Liu, M.-K.; Yang, G.-H.; Li, D.-W.; Li, H.-T. Highly Reproducible Ag NPs/CNT-Intercalated GO Membranes for Enrichment and SERS Detection of Antibiotics. ACS Appl. Mater. Interfaces 2016, 8, 28180-28186. [CrossRef] [PubMed]

106. Cui, J.; Chen, S.; Ma, X.; Shao, H.; Zhan, J. Galvanic Displacement-Induced Codeposition of Reduced-Graphene-Oxide/Silver on Alloy Fibers for Non-Destructive SPME@SERS Analysis of Antibiotics. Microchim. Acta 2019, 186, 19. [CrossRef] [PubMed]

107. Zheng, Z.; Cong, S.; Gong, W.; Xuan, J.; Li, G.; Lu, W.; Geng, F.; Zhao, Z. Semiconductor SERS Enhancement Enabled by Oxygen Incorporation. Nat. Commun. 2017, 8, 1993. [CrossRef]

108. Jiang, X.; Chen, Y.; Du, J.; Li, X.; Shen, Y.; Yang, M.; Han, X.; Yang, L.; Zhao, B. Comparative Study of Semiconductor TiO2 and Noble Metal Ag Substrates: The Differences between Chemical Enhancement and Electromagnetic Enhancement in SERS. J. Raman Spectrosc. 2018, 49. [CrossRef]

109. Wang, W.; Sang, Q.; Yang, M.; Du, J.; Yang, L.; Jiang, X.; Han, X.; Zhao, B. Detection of Several Quinolone Antibiotic Residues in Water Based on Ag-TiO2 SERS Strategy. Sci. Total Environ. 2020, 702, 134956. [CrossRef] [PubMed]

110. Xie, Y.; Zhao, M.; Hu, Q.; Cheng, Y.; Guo, Y.; Qian, H.; Yao, W. Selective Detection of Chloramphenicol in Milk Based on a Molecularly Imprinted Polymer-Surface-Enhanced Raman Spectroscopic Nanosensor: Selective Detection of Chloramphenicol in Milk. J. Raman Spectrosc. 2017, 48, 204-210. [CrossRef]

111. Ashley, J.; Wu, K.; Hansen, M.F.; Schmidt, M.S.; Boisen, A.; Sun, Y. Quantitative Detection of Trace Level Cloxacillin in Food Samples Using Magnetic Molecularly Imprinted Polymer Extraction and Surface-Enhanced Raman Spectroscopy Nanopillars. Anal. Chem. 2017, 89, 11484-11490. [CrossRef]

112. Pinheiro, P.; Fateixa, S.; Nogueira, H.; Trindade, T. Magnetite-Supported Gold Nanostars for the Uptake and SERS Detection of Tetracycline. Nanomaterials 2018, 9, 31. [CrossRef] [PubMed]

113. Chen, Y.; Li, X.; Yang, M.; Yang, L.; Han, X.; Jiang, X.; Zhao, B. High Sensitive Detection of Penicillin G Residues in Milk by Surface-Enhanced Raman Scattering. Talanta 2017, 167, 236-241. [CrossRef] [PubMed]

114. Li, M.; Wu, H.; Wu, Y.; Ying, Y.; Wen, Y.; Guo, X.; Yang, H. Heterostructured Cube Au-Ag Composites for Rapid Raman Detection of Antibiotic Ciprofloxacin: Rapid Raman Detection of Antibiotic Ciprofloxacin. J. Raman Spectrosc. 2017, 48, 525-529. [CrossRef]

115. Bhalla, N.; Jolly, P.; Formisano, N.; Estrela, P. Introduction to Biosensors. Essays Biochem. 2016, 60, 1-8. [CrossRef]

116. Dixon, M.C. Quartz Crystal Microbalance with Dissipation Monitoring: Enabling Real-Time Characterization of Biological Materials and Their Interactions. J. Biomol. Tech. JBT 2008, 19, 151-158.

117. Shen, Y.; Xu, L.; Li, Y. Biosensors for Rapid Detection of Salmonella in Food: A Review. Compr. Rev. Food Sci. Food Saf. 2021, 20, 149-197. [CrossRef]

118. Tan, B.; Zhao, H.; Du, L.; Gan, X.; Quan, X. A Versatile Fluorescent Biosensor Based on Target-Responsive Graphene Oxide Hydrogel for Antibiotic Detection. Biosens. Bioelectron. 2016, 83, 267-273. [CrossRef] [PubMed]

119. Wu, S.; Zhang, H.; Shi, Z.; Duan, N.; Fang, C.; Dai, S.; Wang, Z. Aptamer-Based Fluorescence Biosensor for Chloramphenicol Determination Using Upconversion Nanoparticles. Food Control 2015, 50, 597-604. [CrossRef]

120. Yue, F.; Li, F.; Kong, Q.; Guo, Y.; Sun, X. Recent Advances in Aptamer-Based Sensors for Aminoglycoside Antibiotics Detection and Their Applications. Sci. Total Environ. 2021, 762, 143129. [CrossRef] [PubMed]

121. Ebralidze, I.I.; Laschuk, N.O.; Poisson, J.; Zenkina, O.V. Chapter 1-Colorimetric Sensors and Sensor Arrays. In Nanomaterials Design for Sensing Applications; Zenkina, O.V., Ed.; Micro and Nano Technologies; Elsevier: Amsterdam, The Netherlands, 2019; pp. 1-39. [CrossRef]

122. Ma, Q.; Wang, Y.; Jia, J.; Xiang, Y. Colorimetric Aptasensors for Determination of Tobramycin in Milk and Chicken Eggs Based on DNA and Gold Nanoparticles. Food Chem. 2018, 249, 98-103. [CrossRef]

123. Abedalwafa, M.A.; Li, Y.; Ni, C.; Wang, L. Colorimetric Sensor Arrays for the Detection and Identification of Antibiotics. Anal. Methods 2019, 11, 2836-2854. [CrossRef]

124. Hao, L.; Gu, H.; Duan, N.; Wu, S.; Wang, Z. A Chemiluminescent Aptasensor for Simultaneous Detection of Three Antibiotics in Milk. Anal. Methods 2016, 8, 7929-7936. [CrossRef]

125. Emrani, A.S.; Danesh, N.M.; Lavaee, P.; Ramezani, M.; Abnous, K.; Taghdisi, S.M. Colorimetric and Fluorescence Quenching Aptasensors for Detection of Streptomycin in Blood Serum and Milk Based on Double-Stranded DNA and Gold Nanoparticles. Food Chem. 2016, 190, 115-121. [CrossRef]

126. Marquette, C.A.; Blum, L.J. Electro-Chemiluminescent Biosensing. Anal. Bioanal. Chem. 2008, 390, 155-168. [CrossRef]

127. Yang, L.; Ni, H.; Li, C.; Zhang, X.; Wen, K.; Ke, Y.; Yang, H.; Shi, W.; Zhang, S.; Shen, J.; et al. Development of a Highly Specific Chemiluminescence Aptasensor for Sulfamethazine Detection in Milk Based on in Vitro Selected Aptamers. Sens. Actuators B Chem. 2019, 281, 801-811. [CrossRef]

128. Situ, C.; Mooney, M.H.; Elliott, C.T.; Buijs, J. Advances in Surface Plasmon Resonance Biosensor Technology towards HighThroughput, Food-Safety Analysis. TrAC Trends Anal. Chem. 2010, 29, 1305-1315. [CrossRef]

129. Blidar, A.; Feier, B.; Tertis, M.; Galatus, R.; Cristea, C. Electrochemical Surface Plasmon Resonance (EC-SPR) Aptasensor for Ampicillin Detection. Anal. Bioanal. Chem. 2019, 411, 1053-1065. [CrossRef] [PubMed]

130. Cervera-Chiner, L.; Jiménez, Y.; Montoya, Á.; Juan-Borrás, M.; Pascual, N.; Arnau, A.; Escriche, I. High Fundamental Frequency Quartz Crystal Microbalance (HFF-QCMD) Immunosensor for Detection of Sulfathiazole in Honey. Food Control 2020, 115, 107296. [CrossRef] 
131. Lan, L.; Yao, Y.; Ping, J.; Ying, Y. Recent Advances in Nanomaterial-Based Biosensors for Antibiotics Detection. Biosens. Bioelectron. 2017, 91, 504-514. [CrossRef]

132. Wang, X.; Dong, S.; Gai, P.; Duan, R.; Li, F. Highly Sensitive Homogeneous Electrochemical Aptasensor for Antibiotic Residues Detection Based on Dual Recycling Amplification Strategy. Biosens. Bioelectron. 2016, 82, 49-54. [CrossRef]

133. Munteanu, F.-D.; Titoiu, A.; Marty, J.-L.; Vasilescu, A. Detection of Antibiotics and Evaluation of Antibacterial Activity with Screen-Printed Electrodes. Sensors 2018, 18, 901. [CrossRef]

134. Starzec, K.; Cristea, C.; Tertis, M.; Feier, B.; Wieczorek, M.; Kościelniak, P.; Kochana, J. Employment of Electrostriction Phenomenon for Label-Free Electrochemical Immunosensing of Tetracycline. Bioelectrochemistry 2020, 132, 107405. [CrossRef] [PubMed]

135. Wang, H.; Wang, Y.; Liu, S.; Yu, J.; Xu, W.; Guo, Y.; Huang, J. Target-Aptamer Binding Triggered Quadratic Recycling Amplification for Highly Specific and Ultrasensitive Detection of Antibiotics at the Attomole Level. Chem. Commun. 2015, 51, 8377-8380. [CrossRef] [PubMed]

136. Pilehvar, S.; Gielkens, K.; Trashin, S.A.; Dardenne, F.; Blust, R.; De Wael, K. (Electro)Sensing of Phenicol Antibiotics-A Review. Crit. Rev. Food Sci. Nutr. 2016, 56, 2416-2429. [CrossRef]

137. Pan, M.; Li, S.; Wang, J.; Sheng, W.; Wang, S. Development and Validation of a Reproducible and Label-Free Surface Plasmon Resonance Immunosensor for Enrofloxacin Detection in Animal-Derived Foods. Sensors 2017, 17, 1984. [CrossRef] [PubMed]

138. Mishra, G.K.; Sharma, A.; Bhand, S. Ultrasensitive Detection of Streptomycin Using Flow Injection Analysis-Electrochemical Quartz Crystal Nanobalance (FIA-EQCN) Biosensor. Biosens. Bioelectron. 2015, 67, 532-539. [CrossRef]

139. Fogel, R.; Limson, J.; Seshia, A.A. Acoustic Biosensors. Essays Biochem. 2016, 60, 101-110. [CrossRef] [PubMed]

140. Liu, C.; Lu, C.; Tang, Z.; Chen, X.; Wang, G.; Sun, F. Aptamer-Functionalized Magnetic Nanoparticles for Simultaneous Fluorometric Determination of Oxytetracycline and Kanamycin. Microchim. Acta 2015, 182, 2567-2575. [CrossRef] 